\title{
Internal Migration and Life Satisfaction: \\ Well-Being Effects of Moving as a Young Adult
}

\author{
Malgorzata Switek \\ University of Southern California \\ (Preliminary work)
}

\begin{abstract}
Migration typically leads to higher income, but its effects on life satisfaction remain unclear. Does migration increase life satisfaction? If it does, is the increase in income responsible or are other life domains driving the satisfaction changes? These two questions are addressed using longitudinal data from a Swedish Young Adult Panel Study for 1999 and 2009. Comparing migrants to non-migrants, it is found that internal migration does increase life satisfaction for both, migrants who move due to work and non-work reasons. This finding holds regardless of other life transitions that may accompany migration, such as marriage and joining the labor market. Different channels lay behind the increase in life satisfaction for work and non-work migrants. For both migrant groups, however, these channels are mostly unrelated to income changes. For non-work migrants, improvements in life satisfaction seem to be due to higher housing satisfaction. No increase in income relative to non-migrants is found for this group. For work migrants, changes in occupational composition leading to higher status seem to underlie the higher life satisfaction. Relative income increases experienced by this migrant group are accompanied by constant relative economic satisfaction. The absence of improvements in the economic domain for work migrants implies adaptation to higher earnings.
\end{abstract}


"Life is like riding a bicycle - in order to keep your balance, you must keep moving."

-Albert Einstein

\section{Introduction}

The life of a young adult is filled with changes and transitions. Finding a place to establish one's own future, finishing education, getting married - these are all life events experienced in the early adult life and that potentially tailor future happiness. This paper discusses the effects of one such life event - specifically, migration - on life satisfaction changes. Does internal migration affect the life satisfaction of young adults and is this effect positive? What are the channels through which migration and life satisfaction are related? Is income one of the main drivers of the relationship between migration and life satisfaction? These are the questions addressed.

A longitudinal survey of young adults in Sweden, along with information from the Swedish Register, are used to answer the above questions. To assess the effects of internal migration on life satisfaction, life satisfaction levels of migrants and non-migrants are compared before and after. Other life transitions characteristic of young adults, such as labor market transitions or changes in marital status, are controlled for to avoid possible confounding effects. After investigating the association between migration and life satisfaction, the channels through which this association operates are examined. To assess these channels, specific life domains representing major aspects of life that contribute to overall happiness - such as the economic, housing, or professional satisfaction - are considered. The migrants are divided into those who move for work and non-work reasons throughout the analysis.

Until now, most economic literature has focused on the analysis of the effects of internal migration on income changes. In general, its findings point to a positive association between migration and income. Considerably fewer studies have been carried out analyzing changes in subjective well-being that accompany internal migration, and their results have been much less clear. The unavailability of good longitudinal data providing information about migrants' satisfaction levels both before and after the move, has represented a big limitation for these studies. The few existing panel analyses mostly indicate that migration and life satisfaction are, in fact, positively related. On the related concept of mental health, no consensus has been 
reached either, though the existing evidence suggests a positive association between international migration and mental well-being.

The present paper contributes to the previous literature in several ways. First, the panel structure of the data allows for a comparison of life satisfaction before and after the move for both migrants and non-migrants. Second, the analysis controls for other life transitions experienced by young adults, such as getting married or joining the labor market, which assures a more accurate isolation of the effects of migration. Third, people who migrate for different reasons (work and non-work) are considered separately to see whether the relationship between migration and life satisfaction differs for the two migrant groups. Finally, the relationship between migration and satisfaction with specific aspects of life contributing to life satisfaction referred to as life domains - is considered. Specifically, the economic, housing, and professional life domains are analyzed. This domain analysis further clarifies the mechanisms behind the migration and life satisfaction relationship.

The findings show that internal migration is associated with an increase in life satisfaction for migrants of all types. For both work and non-work migrants, the improvements in life satisfaction are mostly due to reasons unrelated to income changes. For work migrants, the positive relationship between migration and life satisfaction is due mainly to occupational mobility. For non-work migrants, increments in housing satisfaction lie behind the increase in life satisfaction.

\section{Literature Review}

The objective well-being effects of migration have been extensively discussed in the economic literature. Economist have focused mostly on the monetary costs and benefits of internal migration, viewing changes in personal income as one of the main consequences of a move. The roots of this approach may be found in seminal papers that view internal migration as a resource allocation mechanism meant to distribute people from places with low income opportunities to place with high income opportunities (Sjaastad 1962, Harris and Todaro 1970).

Assessing the relationship between migration and income has, however, proven to be a difficult task because of the inexistence of a good comparison group. In theory one would want to know what the migrants' income would have been if they had not moved. In practice, this is not possible. Early studies of the effects of internal migration on income perform cross-sectional 
analyses in which the incomes of the non-migrants (either from the place of origin or the place of destination) are used as a comparison group for the incomes of migrants (Lansing and Morgan 1967, Weiss and Williamson 1972). To account for the differences between the migrants and non-migrants, these papers use extensive sets of control variables. Their results are mixed depending on the migration and control groups used, but mostly favor the idea that internal migration does induce income gains for the migrants.

Since migrants are likely to possess unobservable traits that distinguish them from nonmigrants, cross-sectional comparisons are subject to serious selectivity bias problems (Antel 1980, Borjas 1992). Panel studies which consider income levels both before and after the move have been used as an alternative to the cross-sectional analyses. By analyzing changes, rather than levels, of income, panel studies are able to control for all fixed differences between migrants and non-migrants that may bias the results, accounting for a considerable part of the selectivity bias. This type of studies have also found that, in general, migration is associated with an increase in income, though the effects of migration on income gains may vary by age, reason of move (Bartel 1979), and gender (Lichter 1983, Cooke and Bailey 1996, Finnie 1999, Blackburn 2009).

The association between migration and higher income must not necessarily imply an association between migration and subjective well-being for at least two reasons. First, increasing income may be associated with increasing aspirations for the migrants, which may in turn result in a constant life satisfaction level (Easterlin 2001, Easterlin and Angelescu 2009). Second, the economic domain is not the only life aspect affected by migration that influences changes in subjective well-being. Migration may affect satisfaction with place of residence, current occupation, friendships, and number of other life domains. The final relationship between migration and life satisfaction should reflect the composite impact of all the life domain changes as well as the personal adaptation effects.

Unfortunately, due to limited longitudinal data on life satisfaction and migration, the effects of migration on subjective well-being have not been analyzed thoroughly. Cross-sectional studies point to a negative relationship between migration and life satisfaction (Knight and Gunatilaka 2007, Bartram 2010). However, these studies suffer from the same selectivity bias problems as the cross-sectional income-effect analyses discussed above. In a study of Thailandese migrants, DeJong and coauthors try to control for the self-selection problem of 
cross-sectional data by employing questions about the migrants' own perception of whether the move increased or decreased their satisfaction levels (DeJong 2002). The authors' findings indicate that a non-trivial proportion of migrants report decreased satisfaction levels after the move. However, these results may not be considered conclusive either, as it has been found that self-reported past and future life satisfaction levels are in general inaccurate (Easterlin 2001).

Nowok and coauthors present one of the few longitudinal analyses of the effects of internal migration on life satisfaction (Nowok et al 2011). Employing the British Household Panel Study they find an association between migration and increasing life satisfaction during the year of the move. Their results also show a drop in life satisfaction of migrants three years prior to the move, which may affect the increase in life satisfaction accompanying migration. The authors do not, however, provide an explanation of the causes behind the decrease in life satisfaction prior to migration, nor do they analyze the life domains affecting the changes in life satisfaction after the move.

Studies of the relationship between other satisfaction variables and migration using panel data sets are also rare. The one area that does provide some interesting results, consists of studies analyzing the effects of residential migration. In general, these studies find that housing satisfaction increases as an effect of residential migration (Barcus 2004, Diaz-Serrano 2006). At the same time, bad dwelling characteristics and dissatisfaction with housing is found to be a significant factor increasing the likelihood of migrating for residential reasons (Diaz-Serrano 2006).

A different category of studies closely related to the literature on migration and life satisfaction, is the one assessing the effects of migration on mental health. Mental health of migrants (especially international migrants) as compared to non-migrants has been amply studied by psychologists (Vega et al 1987, Ying 1996, Vega et al 1998). Unfortunately, again, very few studies that would account for the self-selection effect have been carried out in this literature. Summarizing its main findings, Bhugra concludes that, while migration may be a stress-inducing phenomenon, migrant experiences present a lot of variance, and that the impact of migration on mental disorders such as depression is not straightforward (Bhugra 2004a and 2004b).

An important contribution to the economic literature on international migration and mental well-being is made by Stillman and coauthors (Stillman et al 2009). Based on a natural experiment from The Kingdom of Tonga, their study compares the mental health of migrants to 
that of potential migrants, that is, people who would wish to migrate but are (randomly) not allowed to do so. Since being selected randomly into migration is uncorrelated with personal traits, the authors use the random selection as an instrumental variable to estimate the unbiased relationship between migration and mental health. Their findings show that the act of moving from Tonga to New Zealand has a positive effect on mental health of migrants. However, the effects of international and internal migration are likely to differ in a number of ways. Therefore, in spite of its importance, the study by Stillman and coauthors cannot be extrapolated to shed further light on the effects of internal migration. In summary, the association between subjective well-being (as measured by life satisfaction or by mental health) and internal migration remains an open question.

\section{Data description}

Two main data sources are used: the Young Adult Panel Study (YAPS), carried out in Sweden, and the Swedish Register information. The YAPS consists of a longitudinal survey designed by Eva Bernhardt from Stockholm University carried out in the years 1999, 2003 and 2009. It contains data on around 3500 individuals, many of whom were followed throughout the three stages of the study. The Swedish Register data contains information on all Swedish individual's main socio-economic characteristics (such as civil status, place of residence and income), and is collected by the Swedish Tax Agency. Information from the two sources was linked for all individuals interviewed in 2009 to obtain a more complete social, economic, and demographic data set.

Although YAPS interviewed over 3000 individuals in the three years during which it was carried out, only a portion of these people participated in the three waves of the study. The present analysis includes only individuals who were interviewed in both 1999 and 2009, and for whom information on the main variables of interest is available. From the 2820 people initially interviewed in 1999, only 56\% could be re-interviewed ten years later reducing the sample of observations to 1575 individuals, a small portion of whom did not answer certain survey questions used and had to be dropped from the regression analysis ${ }^{1}$. The high attrition rate may create worries about the possible existence of a selectivity bias. The methodology used

\footnotetext{
${ }^{1}$ For complete information on the number of observations available for each of the main variables included in the study, please see Table B1, Appendix B.
} 
throughout the analysis, which controls for all individual level fixed effects as well as some of the main time-varying individual and community level effects, should account for an important part of the differences between attritors and non-attritors, significantly reducing the problems due to selectivity into attrition. A detailed analysis of the remaining differences between attritors and non-attritors provides reassurance that the remaining selectivity bias is small in magnitude, and does not have an important effect on the results of the study (Appendix A).

The two main variables employed in the analysis are life satisfaction and migration status. Life satisfaction is measured in all waves of the YAPS survey using the answer to the question: "How satisfied are you with your life in general?". Response categories are given on a scale from 1 to 5 , with 1 meaning very dissatisfied and 5 very satisfied. Migration status is established using the Swedish Register information about the place of residence of each individual in 1999, 2003 and 2009. A person is classified as a migrant if she changed her municipality in the years under analysis (including those who reported a different municipality in 2003 and later moved back), and as a non-migrant if no such change in place of residence took place. Given the average size of municipalities in Sweden, which is slightly above 500 square miles (Statistics Sweden, 2012), this type of migration would roughly correspond to moving in between two cities of the United States.

The question used to divide the migrants into work and non-work migrants was included in 2009 only and asks the following: "What was the most important reason for you to move?" The possible response categories for this question include "my work/studies" as well as other seven options that were unrelated to the person's work (Table B4, Appendix B). Using the answer to this question, the migrants were classified as either work migrants - if they chose "my work/studies" as their main reason to move, - or non-work migrants - if they chose any of the other response categories.

The variables used to analyze the channels through which migration and life satisfaction are related include disposable and work income, satisfaction with other life domains (economic, housing, and what the person is currently doing), and information on current occupation. Disposable and work income for 1998 and 2008 are given on individual level and are obtained from the Swedish Register records. Income from the years previous to the survey is used, because in both 1999 and 2009 the interviews were conducted at the beginning of the year (between March and May). Therefore, during the time of the survey, the satisfaction levels of the 
respondents were likely to reflect their past years' income. Both disposable and work income from 2008 are adjusted for inflation using the Consumer Price Index available from the Swedish Statistics data bank.

The three additional satisfaction variables used are satisfaction with the economic situation, with housing, and with what the person is currently doing. Satisfaction with relationship with partner, though available in the survey, is not used due to high non-response rates in both years (Table B1, Appendix B). All satisfaction questions were asked using the same format and response scale as life satisfaction. Occupational categories are constructed by combining two survey questions: main occupation, used to classify people as students and unemployed; and main activity, used to classify people into different production sectors of the economy, such as services, non-manual, or professional. The final classification used, groups people as being part of one of the following occupations: goods production, service production, assistant non-manual, intermediate non-manual, professional/higher manual/self-employed, executive/entrepreneur/farmer, student, and unemployed.

The control variables considered are education level, civil status, and a labor market transition indicator. Education is obtained from the Swedish Register where it is reported using six possible levels: compulsory 9 years, secondary less than 3 years, secondary 3 years, postsecondary less than 3 years, post-secondary 3 years or more, and postgraduate. For the purpose of the analysis the last two levels are combined into one category labeled "post-secondary education." The five educational categories obtained are used to approximate the years of education for each individual, setting each level to $9,10.5,12,13.5$ and 16.5 years accordingly. Civil status is also obtained from the Swedish Register, which provides information on whether the person is unmarried, married, widowed or divorced. Given the young age of the subjects surveyed, the widowed and divorced groups are both quite small and are therefore combined for the purpose of the analysis.

The labor market transition variable is used to control for the life satisfaction effects of finishing studies and moving on to occupy a position in the labor market. It consists of an indicator variable that takes on the value of 1 if the person has reached her highest level of education after 1999 and is actively participating in the labor market in 2009 (that is, has reported an occupation or main activity other than student, unemployed, or housekeeping), and 0 
otherwise $^{2}$. Due to its nature it is closely related to the education and occupational category variables, but cannot be completely captured by either of them ${ }^{3}$. For further description of these and other variables employed, please consult Appendix B.

\section{Patterns of internal migration}

The main socio-demographic characteristics of migrants in this study are consistent with those usually observed in developed countries: migrants are mostly young, unmarried, and have higher final education levels than non-migrants. Of the three cohorts considered (born in 1976, 1972, and 1968), the youngest presents the highest level of mobility during the decade under analysis (Table 1). The higher migration rates of the 1976 cohort are consistent with a couple of important demographic findings. First, the age patterns of migrants have been long documented as following regularities, with the rates of migration peaking during young adulthood (Thomas 1938, Beshers and Nishiura 1960, Pandit 1997, Fischer and Malmberg 2001). Second, the 1976 cohort is smaller than the previous ones; it has been observed that smaller cohorts have higher migration rates than larger cohorts because of better labor market conditions (Pandit 1997).

Given the young age of all respondents during the first interview -22 for the youngest cohort and 30 for the oldest - it is not surprising that the overall percent of people married is much higher in 2009 than in 1999 (45\% as compared to 13\%). Migrants are more likely to be unmarried in 1999 than non-migrants, though by 2009 the marriage rates of the two groups are similar (Table 1). The lower initial marriage rates among migrants are consistent with the majority of them belonging to the youngest cohort, and with the finding that movers concentrate among those with fewer social ties at the place of origin (Fischer and Malmberg 2001, Michaelides 2011). Migrants are also more likely to be still studying in 1999 than non-migrants, and to have higher education levels in both 1999 and 2009 (Table 1). This pattern coincides with studies finding that Swedes with higher education levels are more prone to move (Kupiszewski et al 2001). The higher percent of students among migrants in 1999 is probably observed because

\footnotetext{
${ }^{2}$ For the detailed reasoning behind the construction of the labor market indicator, please see the methods section.

${ }^{3}$ Though the labor market transition indicator is closely related to changing occupational categories from "student" to any other category, it is not equivalent to such a change. Consider, for example, the case of a young adult who is employed in 1999, but later decides to go back to school to finish studies. If this person achieves her highest level of education between 2000 and 2009, and is employed in 2009, she would be considered to have gone through a labor market transition. However, her occupational category in 1999 would not have been "student".
} 
completion of schooling and the subsequent transition into the labor market are both strongly associated with migration (Fischer and Malmberg 2001).

As is true of many other developed countries, internal migration in Sweden has been characterized by flows from both rural to urban (urbanization) and urban to rural (counterurbanization) areas in the past decades (Kupiszewski et al 2001, Plane et al 2005). For the purpose of the present study, migration between all types of counties and municipalities is combined for two reasons. First, the main focus of the analysis is on the association between any internal move and life satisfaction, regardless of its urbanizing or counter-urbanizing effects. Second, considering the YAPS migrants as a whole, the share of overall migration between urban and rural areas, whatever the direction, is small. Dividing the Swedish counties into predominantly urban and predominantly rural $^{4}$, it is observed that over $70 \%$ of the migrants in the sample move within counties of a given type (Table 2). For the remaining $30 \%$, the direction of internal migration is associated with the age of the migrant. The migrants from the youngest cohort are the most likely to make a move from a rural to an urban county, and those from the oldest cohort are the most likely to make a move in the opposite direction. This is consistent with what has been observed for recent migration patterns in Sweden (Kupiszewski et al 2001).

\section{Methods}

The main problem faced assessing the effects of migration on life satisfaction, is the lack of a perfect comparison group. Though in theory one would like to compare the migrant's life satisfaction to what it would have been had she not moved, in practice this counterfactual is impossible to observe. Therefore one is left with the second best option: comparing the life satisfaction of migrants to that of non-migrants, controlling for the possibility of endogeneity due to a selectivity bias.

Endogeneity due to selectivity arises when migrants and non-migrants differ in ways that are related to both their life satisfaction and their migration status. Some of these problematic differences are observable and may be accounted for in a regression analysis, as long as the appropriate set of control variables is included. Some are unobservable and need to be controlled for in different ways. This section describes the methods used in the analysis, focusing on the

\footnotetext{
${ }^{4}$ This division was based on the OECD Territorial Review of Sweden (OECD 2010). Stockholm, Vastra Gotaland, and Skane are the three counties classified as predominantly urban; the rest of the counties are classified as predominantly rural.
} 
techniques which account for the differences between migrants and non-migrants. In the first part the methods used to account for the unobservable differences between the two groups are discussed. The second part deals with the selection of the appropriate control variables to be included in the regression analysis. Final methodological issues related to missing values, econometric techniques, and the analysis of the channels through which migration and life satisfaction may be related, are discussed in the last part of the section.

\section{$\underline{5 a}$. Dealing with endogeneity - the problem of unobservables}

Unobservable characteristics that affect both, a person's migration status, and her life satisfaction level may be of two types: fixed and time-varying. An important type of fixed characteristics that could represent a source of endogeneity are individual level personality traits that make specific people more prone to migration. For example, imagine that optimists are both, more likely to migrate, and to report higher satisfaction levels. Since optimism is unobservable making it impossible to control for - its relationship with life satisfaction and migration could potentially bias the analysis.

Other types of unobservable characteristics may be time-varying. A good example are community level shocks taking place between the two dates of the surveys. Imagine the case of a natural disaster, such as a flood. A flood could permanently lower life satisfaction of the people affected by it and, at the same time, have damaging effects on the community where it occurs, influencing the likelihood of its residents to become migrants. These shocks represent unobservable externalities and introduce another source of bias. Notice that the community shocks are different from community fixed effects (such as weather) which remain constant over time, and may be accounted for by introducing place of residence controls. The community shocks are, on the contrary, time varying, and should therefore be accounted for separately.

The following model represents the life satisfaction of individual i, in community $\mathrm{c}$, at time $t$, taking into account the variables previously described that could affect both life satisfaction and migration:

(1) $\mathrm{Y}_{\mathrm{cit}}=\mu_{\mathrm{t}}+\eta_{\mathrm{i}}+\theta_{\mathrm{c}}+\rho_{\mathrm{c}}{ }^{*} \mathrm{t}+\beta^{\prime} \mathrm{x}_{\mathrm{it}}+\gamma \mathrm{M}_{\mathrm{it}}+\varepsilon_{\mathrm{cit}}$

where: $Y_{\text {cit }}$ is the outcome variable of interest (in this case life satisfaction); $\mu_{t}$ is a time effect, $\eta_{i}$ is the individual fixed effect, $\theta_{\mathrm{c}}$ is the community fixed effect (e.g. weather), $\rho_{\mathrm{c}}$ is the external shock 
affecting the community between periods 0 and 1 (e.g. a flood), $t$ is a time dummy, $x_{i t}$ is a vector of observable individual characteristics; $M_{i t}$ is the migration status which at time 0 is equal to 0 for all individuals, and at time 1 is equal to 0 for non-migrants and to 1 for migrants; and $\varepsilon_{\text {cit }}$ is an error term. Notice that since $\rho_{\mathrm{c}}$ occurs after time 0 , it will only affect life satisfaction of the people originally from community c, at time 1 (which is why it is being interacted with a time dummy). Also, since the effect of the shock is assumed to be permanent, it will influence $Y_{\text {cit }}$ for all people originally from the affected region regardless of their place of residence in the next period (i.e. regardless of their decision to migrate or not in between periods 0 and 1$)^{5}$.

The time-varying individual and community level unobservable characteristics from model (1) may be captured in the following econometric regression:

(2a) $Y_{c i t}=\mu D_{t}+\eta_{i}+\theta_{c}^{*} D_{c t}+\rho\left(D_{c 0} * D_{t}\right)+\gamma\left(M_{i}^{*} D_{t}\right)+\beta^{\prime} x_{i t}+\varepsilon_{c i t}$

where:

$D_{t}$ is the time dummy equal to 0 at $t=0$ and 1 at $t=1 ; D_{c t}$ is a vector of dummies for the community of residence at time $t ; D_{c 0}$ is a vector of dummies for the original community of residence (i.e. place of residence at time 0 ); and $\mathrm{M}_{\mathrm{i}}$ is the migration dummy equal to 0 for nonmigrants and 1 for migrants. Taking a first difference (FD) of (2a) to account for the individual fixed effects yields the final regression employed in the analysis:

$\Delta \mathrm{Y}_{\mathrm{ci}}=\mu+\theta\left(\mathrm{D}_{\mathrm{c} 1}-\mathrm{D}_{\mathrm{c} 0}\right)+\rho \mathrm{D}_{\mathrm{c} 0}+\gamma \mathrm{M}_{\mathrm{i}}+\beta^{\prime} \Delta \mathrm{x}_{\mathrm{i}}+\Delta \varepsilon_{\mathrm{ci}}$

Here the individual fixed effect has been eliminated using the first difference. The community fixed effects and the regional shocks are both controlled for by including $\left(\mathrm{D}_{\mathrm{c} 1}-\mathrm{D}_{\mathrm{c} 0}\right)$ and $\mathrm{D}_{\mathrm{c} 0}$ respectively. Using this approach, the regression employed in the analysis avoids the fixed and time-varying biases discussed above. In this setting $\mathrm{M}_{\mathrm{i}}$ captures the pure association between being a migrant and a life satisfaction change, controlling for the observable differences between migrants and non-migrants.

\footnotetext{
${ }^{5}$ This statement holds under the assumption that the shock is related to the decision to migrate and therefore the migrants will have been present at community c during its occurrence and will only make the decision to move after this event. If no shock occurs at a community between periods 0 and 1 or if a shock takes place that is unrelated to the migration decision, then it would not be a source of endogeneity and so it would not bias the results. In that case $\rho_{\mathrm{c}}=0$.
} 
In (2b) any binomial control is converted into a categorical variable taking on the values of $-1,0$ or 1 . For example, in the case of a dummy for residence in a given community at time $t$, the FD regression will include variables taking on the value of -1 if a person left this community between periods 0 and 1, 1 if the person entered it, and 0 if the person neither left nor entered this community. The community dummies used are based on the county of residence, which is a more comprehensive geographic unit than municipality. Since the migration status of a person is defined using the municipality changes, municipality of residence may be considered as a more appropriate control. However, due to the large number of municipalities (over 250 as compared to 21 counties), the use of controls at the more specific regional level results impractical. As a robustness check, an alternative classification of migration status is employed, defining a person as a migrant if she changed her county of residence between 1999 and 2009. The regression results of the robustness check confirm the main results of the study presented in the following section (Tables $\mathrm{C} 1$ and $\mathrm{C} 2$, Appendix C).

The main assumption behind regression ( $2 b)$, is that the individual and regional effects described are the only sources of endogeneity. In reality, other sources - like household timevarying shocks or interactions between fixed and time-varying effects - may exist. A good way of controlling for any source of endogeneity would be by using an instrumental variable. However, suitable instruments for migration are difficult to obtain and have been found only in rare cases, such as Munshi 2003, when rainfall data was used as an instrument for migration patterns of Mexican workers into the U.S. (Munshi 2003). The search for a good instrument is even more difficult in the case of internal migration. The use of a weak instrument is not appropriate as it has been shown that, even with large sample sizes, instruments that only have a small correlation with the explanatory variable can lead to substantial biases (Wooldridge 2002). Therefore, considering the limitations involved in the analysis, the model presented in $(2 b)$, which does control for unobservable individual and community effects, is considered as the most suitable approach.

\section{$\underline{5 b}$. The choice of observable control variables}

In regression (2b), $\mathrm{x}_{\mathrm{it}}$ represents a vector of individual characteristics that accounts for observable differences between migrants and non-migrants that may affect their life satisfaction level. The choice of appropriate control variables to be included in this vector is as important as 
the use of appropriate econometric techniques to control for unobservable bias sources. Choosing the control variables one should ask: what are the observable characteristics of an individual that may affect both, her life satisfaction and whether she becomes a migrant or not?

Marriage and entering the labor market are two important transitions that may accompany migration and influence a person's life satisfaction. A seen in the preliminary analysis, migrants are more likely to be unmarried in 1999 and to change marital status in between the two surveys than non-migrants. At the same time, marriage has been found to significantly increase life satisfaction (Zimmermann and Easterlin 2006). Therefore, unless changes in marital status are included in the control variables vector of regression (2b), the life satisfaction effects of getting married could be confounded with those of migration.

As to transitions into the labor market, previous literature has found that the migration patterns of young adults seem to be strongly related to labor market changes (Graves 1979, Cuba and Hummon 1993, Chen and Rosenthal 2008). The migrants observed in the YAPS are more likely to be studying in 1999 than non-migrants, which means a higher proportion of them may be finishing studies and entering the work force in between the two surveys (Table 1). A life event such transitioning into the labor market is very likely to have a strong impact on a young adult's well-being (Murphy et al 2010). Therefore, this transition should be controlled for to avoid confounding its effects with those of migration. In the present analysis, a person is considered as having gone through a "labor market transition" in between the two surveys if she reaches her highest education level after 1999, and is actively participating in the labor market in 2009. Notice that this definition does not imply the need to be a student in 1999 - as long as the highest education level is achieved after this year, any occupation may have been reported during the first survey. The broader definition is used because of the fact that many young adults in Sweden take a year or more off before college to travel or work at a low paid occupation before continuing their studies (Cook and Furstenberg 2002).

Changes in education and occupation may both be related to migration and life satisfaction. However, they are not included as control variables in the main regressions for different reasons. Education changes are closely related to labor market transitions - though not all people transitioning to the labor market must have the same change in years of education, all those not going through a labor market transition may be identified as having no change in education. Therefore, due to multicollinearity concerns, this variable is not included in the main 
regressions, though it is used later as a robustness check (Tables C3 and C4, Appendix C). Changes in occupation may also be highly related to labor market transitions, but that is not the main reason why they are not included as control variables. Just as income, a change in occupation may be the channel through which migration and life satisfaction are related. If migration affects life satisfaction through changes in occupation leading to improvements in the professional domain, then controlling for changes in occupation would mitigate the positive relationship between migration and life satisfaction. Occupation controls could therefore introduce a negative bias in the results, and are therefore not used in the analysis. Instead, occupation changes are considered later as one of the possible channels through which migration and life satisfaction may be related.

Other differences between migrants and non-migrants include age and final education level. These variables, though certainly related to life satisfaction in levels, should not affect life satisfaction changes for migrants and non-migrants differently, and therefore do not need to be included as control variables in a first difference regression. The ceteris paribus (i.e. controlling for individual characteristics) relationship between age and life satisfaction presents a $U$ pattern, reaching the low point around age 46 in European countries (Blanchflower and Oswald 2008). Given their young age, all YAPS respondents are on the down-turn of the life satisfaction/age relationship between the time of the two interviews. Therefore the change in age should affect the change in life satisfaction similarly for all of them, regardless of the migration status. Cohort effects, which have been found to significantly influence life satisfaction (Easterlin 2001), are fixed and are eliminated in the first difference regression used. The case of final education is similar. Obtaining a college education sets people on a different life trajectory with consistently higher life satisfaction levels (Easterlin 2001). However, by the age of 22, which is the age of the youngest cohort during the first interview, this trajectory has been already defined, and so it represents a fixed effect.

\section{5c. Other methodological concerns}

Two additional methodological concerns are faced: the ordinal nature of the life satisfaction variable, and a problem of missing values in the reason to move question used to divide migrants into work and non-work migrants. Regarding the first, the usual methods used in the analysis of ordinal dependent variables include ordered probit and ordered logit regressions. However, it has 
been shown that FD maximum likelihood regressions face serious problems that restrict the validity of their results (Han and Phillips 2011). Previous analyses in the life satisfaction literature have demonstrated that the use of ordinary least squares with categorical variables that contain as few as three categories lead to results that are quite similar to those obtained by nonlinear methods (Blanchflower and Oswald 2004). The first difference satisfaction variable used in the analysis contains as many as nine categories, which should justify the use of OLS methods even further. Therefore the present study follows previous literature on life satisfaction (Carter and McBride 2010, Layard et al 2008) and uses the OLS approach in the analysis of the categorical satisfaction variables.

The YAPS survey allows for the division into work and non-work migrants using a question asked in 2009 about whether the person had made a long distance move in the past years, and the reasons why this move had been made. The use of this question, however, creates a missing data problem: out of the 643 migrants in the analysis, 77 did not answer the reason of move question and so could not be classified as either work or non-reason movers. Two methods are used to account for this problem: likewise deletion and multiple imputation. Out of the traditional techniques employed to treat missing data, likewise deletion has been suggested to be as good as any of the other approaches. However, when large proportions of data are missing more advanced methods such as multiple imputation have been found to work best (Sheffer 2002). The present study uses imputation by chained equations (ICE), in which imputed values for the missing variable (in this case, reason to migrate) are generated from a series of univariate models. Using this technique a single variable is imputed based on a group of personal characteristics which includes both the independent and dependent variables from the regression $\operatorname{model}^{6}$ (von Hippel 2007). ICE was preferred over the multivariate normal imputation approach as it results easier when ordinal (or binomial, as in this case) variables are imputed.

The methods so far outlined bear on answering the first question of the study which addresses the relationship between migration and life satisfaction. The second question asks about the channels behind this relationship. To assess these channels, different aspects of life -

\footnotetext{
${ }^{6}$ The exact model for the multiple imputation of reason to migrate (a binary variable for migrants defined as work or other) included the following variables: gender, life satisfaction in 99 and 09, disposable and work income in 99 and 09, satisfaction with housing in 99 and 09 , economic satisfaction in 99 and 09 , satisfaction with occupation in 99 and 09 , satisfaction with partner in 99 and 09 , civil status changes between 99 and 09 , and occupation changes between 99 and 09 . For more information on the ICE method and how its results compare to other imputation techniques please see Ambler et al 2007.
} 
referred to as life domains - that compose overall life satisfaction are analyzed. The analysis of life domains is not new to the subjective well-being literature. Specific life domains - such as satisfaction with economic situation, family, work, and health - have been found to explain patterns of life satisfaction over time in the United States (Easterlin and Sawangfa 2009). A life event may, moreover, affect different life domains in opposite directions. For example, in the United States, as people age their satisfaction with health decreases, but their satisfaction with the economic situation increases over time, contributing to a fairly flat life satisfaction pattern over the life cycle (Easterlin 2006). Given that migration is accompanied by changes in several aspects of life - such as income, housing, and work - one could expect that such an event may affect life satisfaction by impacting several life domains in, possibly, differing ways.

Three life domains - economic, housing, and professional - are considered as possible channels for the association between life satisfaction and internal migration. For each, its relationship with migration is assessed. The main assumption is that if the increase in life satisfaction for migrants as compared to non-migrants comes accompanied by improvements in a specific life domain, than this domain represents a likely channel behind the migration/life satisfaction relationship. To analyze the association between the economic domain and migration, regression (2b) is ran with income and economic satisfaction as dependent variables. For the housing domain, the same procedure is followed with housing satisfaction as the dependent variable. The analysis of the professional domain is complicated by the absence of an adequate variable to reflect job satisfaction. The question most similar to job satisfaction available in the YAPS survey asks about the level of satisfaction with what the person is "currently doing." However, satisfaction with what the person is currently doing is a broad question that may include activities unrelated to a person's occupation. Therefore, this satisfaction variable may not provide an adequate reflection of the professional domain.

To complete the analysis of the professional domain, changes in occupation during the decade under analysis are considered. The goal is to assess whether the patterns of changes in occupation are different for migrants than non-migrants, and whether these differences could be conductive to higher life satisfaction for the migrant group. To facilitate this analysis, occupation categories are divided into three groups for each year: those with relatively low, medium, and high life satisfaction levels respectively. This division is made based on the mean life satisfaction 
levels by occupation category, reported by the YAPS respondents in 1999 and $2009^{7}$. In both years, the occupations with the lowest life satisfaction levels are students and unemployed. In 1999 the medium satisfaction occupations are service and goods production, and assistant and intermediate non-manual; the high satisfaction occupations are professional/higher nonmanual/self-employed, and executives/entrepreneurs/farmers. In 2009 the only high satisfaction occupation is professional/higher-non manual/self-employed; goods and service production, assistant and intermediate non-manual, and executives/entrepreneurs/farmers are all included in the medium satisfaction category (Table B2, Appendix B).

Using this division, mobility matrices are constructed that reflect movements in between occupations with different life satisfaction levels. That is, if a person is a student in 1999 and a professional worker in 2009, this will be reflected as a movement from a low to a high life satisfaction occupation. The analysis of these movements helps to identify patterns of occupational changes that could lead to higher life satisfaction. If, for example, the professional domain is an important channel behind increasing life satisfaction for migrants, than we would expect a higher mobility from lower to higher life satisfaction occupations for migrants than for non-migrants. In the opposite case, an absence of differences in the occupational mobility patterns for migrants as compared to non-migrants, would indicate that the professional domain is not behind the life satisfaction/migration association.

\section{Results}

6a. Migration and life satisfaction

Does life satisfaction increase more for internal migrants than for non-migrants? The answer to this question is a robust yes, and it holds regardless of other life transitions that may accompany young adulthood, and regardless of the reasons behind migration. Life satisfaction increases more for migrants than for non-migrants both when the whole population is considered, and when the population is divided into those who are, and who are not going through a labor market transition in the decade under analysis (column 12, Table 3). When migrants are divided into those who move for work and non-work reasons the positive relationship remains: both work and non-work migrants experience higher increases in life satisfaction than non-migrants regardless

\footnotetext{
${ }^{7}$ For more information about life satisfaction by occupation category in the YAPS survey please see Appendix B, Table B2.
} 
of whether they are, or are not, going through a labor market transition (columns 4 and 8, Table 3). Regression results further confirm these findings. Migration presents a positive and significant association with changes in life satisfaction controlling for time-varying and fixed sources of endogeneity, and for both marital and labor market transitions (columns 1 and 2 , Table 4). Again, the positive and significant association holds when the migrants are divided into those who move for work and non-work reasons (columns 3-6, Table 4).

The importance of considering other life transitions in the analysis of migration is also made clear in the results. Going through a labor market transition, in itself, has a positive effect on the change in life satisfaction (column 15, Table 3). At the same time, a much higher proportion of migrants than non-migrants $-46 \%$ of all migrants, as compared to only $28 \%$ of non-migrants - goes through this transition, which creates a positive bias in the relationship between migration and life satisfaction. The migration and life satisfaction relationship is robust to this bias (column 2, Table 4). However, the mere existence of this problem demonstrates the need to control for life transitions in the regression analysis.

\section{6b. The channels behind the migration and life satisfaction association}

To assess the channels behind the positive association between migration and life satisfaction, changes in three different life domains - economic, housing, and professional - are analyzed. One would expect that if one specific life domain is driving the migration/life satisfaction association, then improvements in this life domain should be observed for migrants as compared to non-migrants. For example, imagine that the increase in life satisfaction for work migrants is due exclusively to economic improvements. In that case an increase in both income and economic satisfaction should be observed for work migrants as compared to non-migrants; no differential improvements in the other life domains should be observed for this migrant group. Since the effects of migration on specific life domains may depend on the reason behind the move, in what follows work and non-work migrants are considered separately.

The channels behind the increasing life satisfaction do in fact differ for work and nonwork migrants. In the case of work migrants, the effects of migration are complex: even though they experience increases in income above those of non-migrants, it is the professional, not the economic, channel that seems to mediate their increasing life satisfaction. Being a work migrant - compared with being a non-migrant - is significantly and positively related to work and 
disposable income changes over the period under analysis, but has an insignificant effect on economic satisfaction and housing satisfaction changes (columns 2-12 Table 5). The lack of an association between work migration and changes in economic satisfaction, implies that this type of migrants adapt fully to their new income and do not experience improvements in the economic domain, discarding this as a possible channel behind their increasing life satisfaction. The housing channel is also rejected due to the null effect of work migration on changes in satisfaction with housing.

An analysis of changes in the professional domain provides more promising results. A comparison of the occupational mobility of work migrants and non-migrants indicates patterns that are likely to be conductive to higher satisfaction levels. Work migrants generally display a much higher mobility in between occupations with different life satisfaction rankings - only $34 \%$ of work migrants, as compared to $62 \%$ of non-migrants, stay in occupations with the same ranking in between 1999 and 2009 (Table 6). The majority of work migrants move into occupations with a higher life satisfaction ( $60 \%$ as compared to $29 \%$ of non-migrants), and the proportion of work migrants moving from a low to a high life satisfaction occupation is almost four times higher than that of non-migrants (27\% vs. 7\%) (Table 6).

These occupational changes are not accompanied by higher differential satisfaction with what the person is currently doing for work migrants (columns 14 and 15 Table 5). However, the lack of an association between satisfaction with what the person is currently doing and workrelated migration does not disqualify the possibility of improvements in the professional domain. As mentioned before, satisfaction with what the person is doing is a broad question that may not reflect exclusively the professional domain. Moreover, occupational shifts in themselves have been found to have a long-term impact on life satisfaction through changes in status. DiTella and co-authors find that moving into an occupation with higher status has a long lasting impact on life satisfaction, as opposed to the effects of increases in income which may also accompany occupational shifts, and which deteriorate rapidly over time as people adapt (DiTella et al 2010). Consistently, the increases in life satisfaction associated with work-related migration observed are likely to be the product of shifts into occupations with higher status, which is reflected by work migrants shifting into occupations with high life satisfaction levels.

Non-work migrants represent a different case: for them, the relationship between migration and life satisfaction appears to be mediated solely through improvements in the 
housing domain. Housing satisfaction of non-work migrants displays increases above those of non-migrants, as captured by the positive and significant effects of non-work migration on satisfaction with housing (columns 11 and 12, Table 5). The economic and professional domains, on the contrary, do not appear to be associated with non-work migration. For both income and economic satisfaction, the effects of being a non-work migrant are never significant, and in some cases display coefficients that are not even positive (columns 2-9, Table 5). The same is true for satisfaction with what a person is currently doing, which displays no association with non-work migration (columns 14-15, Table 5). Moreover, though a bigger proportion of non-work migrants than of non-migrants moves into jobs with higher life satisfaction ranking - $43 \%$ versus $29 \%$ non-work migrants also represent the group with the highest mobility into the lowest life satisfaction occupations (Table 6). Therefore, it is unlikely that the professional domain is responsible for the rise in life satisfaction for this migrant group.

\section{Conclusions}

Previous studies have found a positive association between migration and objective well-being as measured by objective variables such as income, but until now little conclusive evidence has been found on an association between internal migration and changes in subjective well-being. The present study uses a longitudinal approach to assess the changes in life satisfaction that accompany migration by comparing satisfaction levels of migrants and non-migrants before and after the move. Strong evidence of a positive association between internal migration and life satisfaction is found for young adults in Sweden. This association is true for both people who move due to work and non-work reasons, and holds controlling for some of the main sources of endogeneity often present in regressions analyzing the effects of migration, and for other life transitions that may occur during young adulthood.

Life satisfaction increases through different channels depending on the reason behind migration. For work migrants, movement from low to high life satisfaction occupations that accompany migration, seem to be the main driver of increasing life satisfaction through their positive effects on the professional life domain. Though work migrants experience an increase in income above that of non-migrants, their satisfaction with economic situation is not affected differentially by migration. The fact that work migrants' economic satisfaction does not increase more than that of non-migrants, despite their greater income growth, implies adaptation to higher 
earnings and null effects of migration on the economic domain. For non-work migrants, increasing satisfaction with the housing domain drives the positive association between migration and life satisfaction. Non-work migrants do not experience increases in income or economic satisfaction above those of non-migrants, and they do not display the occupational changes conductive to increasing life satisfaction observed for the work migrants.

The finding that migration affects life satisfaction through different channels for work than for non-work migrants is interesting for two reasons. First, it demonstrates the importance of considering work and non-work migrants separately, especially in studies that analyze the well-being effects of migration. Second, it indicates that an increase in income is neither sufficient nor necessary for a positive relationship to exist between migration and life satisfaction. Work migrants, who do experience an increase in income above that of nonmigrants, seem to adapt to their higher earnings. It is the improvement in occupational status that increases life satisfaction of work migrants. Non-work migrants do not experience a differential increase in income, and yet do experience life satisfaction increasing with migration because of improvements in their housing situation.

The findings of the study are specific to internal migration in a developed country where both urbanization and counter-urbanization processes are occurring and may not extend to ruralurban or international migration. Analyses of the subjective well-being effects of different types of migration until now have been restricted by the lack of longitudinal data including satisfaction variables. At the same time, the few life satisfaction studies that have worked with panel data, have not considered the analysis of changes in specific life domains as a result of migration. An interesting path for future research could therefore involve an assessment of life satisfaction and life domain changes for other types of migrants - such as international migrants - to assess whether their experiences are similar to those of the internal migrants described in this study. 


\section{References}

Ambler G. and Omar R.Z. (2007). A comparison of imputation techniques for handling missing predictor values in a risk model with a binary outcome. Statistical Methods in Medical Research 16: $277-298$.

Antel J.J. (1980). Returns to Migration: Literature Review and Critique. RAND note N-1480NICHD.

Barcus H. (2004). Urban-Rural Migration in the USA: An Analysis of Residential Satisfaction. Regional Studies 38(6): 643-657.

Bartel A.P. (1979). The Migration Decision: What Role Does Job Mobility Play? The American Economic Review 69(5):775-786.

Bartram D. (2010). Economic Migration and Happiness: Comparing Immigrants' and Natives' Happiness Gains From Income. Social Indicators Research Online First Version, Published online: 27 August 2010.

Beshers J.M. and Nishiura E.N. (1960). A Theory of Internal Migration Differentials. Social Forces, 1960-1961: 214-218.

Bernhardt, Eva. Family and Working Life in the $21^{\text {st }}$ Century [computer file]. Centre for Gender Studies, Stockholm University and Swedish Institute for Social Research (SOFI), Stockholm University [producers], 2007. Gothenburg, Sweden: Swedish Social Science Data Service (SSD) [distributor], 2007.

Bhugra, D. (2004a). Migration and mental health. Acta Psychiatrica Scandinavica 109: 243-258.

Bhugra, D. (2004b). Migration and depression. Acta Psychiatrica Scandinavica 108(Suppl. 418): 67-72.

Blackburn M.L. ( 2009). Internal migration and the earnings of married couples in the United States. Journal of Economic Geography, 10: 87-111.

Blanchflower D.G. and Oswald A.J. (2004). Well-being over time in Britain and the USA. Journal of Public Economics, 88(7-8): 1359-1386.

Blanchflower D.G. and Oswald A.J. (2008). Is well-being U-shaped over the life cycle? Social Science \& Medicine, 66: 1733-1749.

Borjas G.J., Bronars S.G. and Trejo S.J. (1992a). Self-selection and Internal Migration in the United States. NBER Working Paper No. 4002.

Carter S. and McBride M. (2010). Experienced Utility versus Decision Utility: Putting the ' $S$ ' in Satisfaction. Working paper, mimeo.

Chen Y. and Rosenthal S.S. (2008). Local amenities and life-cycle migration: Do people move for jobs or fun? Journal of Urban Economics, 64: 519-537. 
Cook T.D. and Furstneberg F.F.Jr. (2002). Explaining Aspects of the Transition to Adulthood in Italy, Sweden, Germany, and the United States: A Cross-Disciplinary, Case Synthesis Approach. Annals of the American Academy of Political and Social Science, 580: 257-287.

Cooke T.J. and Bailey A.J. (1996). Family Migration and the Employment of Married Women and Men. Economic Geography, 72(1): 38-48.

Cuba L. and Hummon D.M. (1993). Constructing a Sense of Home: Place Affiliation and Migration across the Life Cycle. Sociological Forum, 8(4): 547-572.

DeJong G.F., Chamratrithirong A. and Tran Q. (2002). For Better, for Worse: Life Satisfaction Consequences of Migration. International Migration Review 36(3): 838-863.

Diaz-Serrano L. (2006). Housing Satisfaction, Homeownership and Housing Mobility: A Panel Data Analysis for Twelve EU Countries. IZA Discussion Paper No. 2318.

DiTella R., Haisken-DeNew J. and MacCulloch R. (2010). Happiness adaptation to income and to status in an individual panel. Journal of Economic Behavior and Organization 76: 834-852.

Easterlin R.A. (2001a). Income and Happiness: Towards a Unified Theory. The Economic Journal 111: 465-484.

Easterlin R.A. (2001b). Life cycle welfare: Trends and differences. Journal of Happiness Studies, 2:1-12.

Easterlin R.A. (2006). Life cycle happiness and its sources: Intersections of psychology, economics, and demography. Journal of Economic Psychology 27: 463-482.

Easterlin R.A. and Angelescu L. (2009). Happiness and Growth the World Over: Time Series Evidence on the Happiness-Income Paradox. IZA Discussion Paper No. 4060.

Easterlin R.A. and Sawangfa O. (2009). "Happiness and Domain Satisfaction: New Directions for the Economics of Happiness", in A.K. Dutt and B. Radcliff, eds., Happiness, Economics, and Politics: Towards a Multi-Disciplinary Approach, Northampton, MA., Edward Elgar, pp. 70-94

Finnie R. (1999). Inter-Provincial Migration in Canada: A Longitudinal Analysis of Movers and Stayers and the Associated Income Dynamics. Canadian Journal of Regional Science 22(3): $227-262$.

Fischer P.A. and Mamberg G. (2001). Settled People Don't Move: On Life Course and (Im-) Mobility in Sweden. International Journal of Population Geography, 7:357-371.

Graves P.E. (1979). A Life-Cycle Empirical Analysis of Migration and Climate, by Race. Journal of Urban Economics, 6: 135-147.

Han C. and Phillips P.C.B. (2011). First Difference MLE and Dynamic Panel Estimation. Cowles Foundation Discussion Paper No. 1780. 
Harris J.R. and Todaro M.P. (1970). Migration, Unemployment and Development: A TwoSector Analysis. The American Economic Review, 60(1): 126-142.

Knight J. and Gunatilaka R. (2007). Great Expectations? The Subjective Well-Being of RuralUrban Migrants in China. Department of Economic Discussion Paper Number 322, University of Oxford.

Kupiszewski M., Borgegard L., Fransson U., Johan H., Durham H. and Rees P. (2001). Internal Migration and Regional Population Dynamics in Europe: Sweden Case Study. School of Geography, University of Leeds, Working Paper 01/01.

Lansing J.B. and Morgan J.N. (1967). The Effects of Geographical Mobility on Income. The Journal of Human Resources, 2(4): 449-460.

Layard R., Mayraz G. and Nickell S. (2008). The Marginal Utility of Income. Journal of Public Economics 92(8-9): 1846-1857.

Lichter D.T. (1983). Socioeconomic Returns to Migration among Married Women. Social Forces, 62(2): 487-503.

Michaelides M. (2011). The effect of local ties, wages, and housing costs on migration decisions. Journal of Socio-Economics, 40(2): 132-140.

Munshi K. (2003). Networks in the Modern Economy: Mexican Migrants in the U.S. Labor Market. The Quarterly Journal of Economics, 118(2): 549-599.

Murphy K.A., Blustein D.L., Bohlig A.J. and Platt M.G. (2010). The College-to-Career Transition: An Exploration of Emerging Adulthood. Journal of Counseling and Develompent, 88(2): 174-181.

Nowok B., van Ham M., Findlay A.M. and Gayle V. (2011). Does Migration Make You Happy? A Longitudinal Study of Internal Migration and Subjective Well-Being. IZA Discussion Paper No. 6140.

Pandit K. (1997). Migration: How Demographic and Economic Cycles Influence the Migration Schedule. Annals of the Association of American Geographers, 87(3): 439-450.

Scheffer J. (2002). Dealing with Missing Data. Research Letters in the Information and Mathematical Sciences 3: 153-160.

Sjaastad L.A. (1962). The Costs and Returns of Human Migration. Journal of Political Economy, 70(5): 80-93.

Stillman S., McKenzie D. and Gibson J. (2009). Migration and mental health: Evidence from a natural experiment. Journal of Health Economics 28(2009): 677-687.

Statistics Sweden. Register data compilations: the Register of Education, the Register of Income and Taxation, and the Total Population Register. 
Statistics Sweden Database. Economic Statistics: Prices and consumption. Available at: http://www.scb.se/Pages/SubjectArea 11537.aspx [accessed March 2011].

Statistics Sweden Database. Environment: Land and water areas. Available at: http://www.scb.se/Pages/ProductTables 12833.aspx [accessed February 2012].

Thomas D. (1938). Research memorandum on Migration Differentials. New York: Social Science Research Council.

Weiss L. and Williamson J.G. (1972). Black Education, Earnings, and Inter-regional Migration: Some New Evidence. The American Economic Review, 62(3): 372-383.

Wooldridge J.M. (2002). Econometric Analysis of Cross Section and Panel Data. United States: Massachusetts Institute of Technology p. 104.

Vega, W.A., Kolody B. and Valle J.R. (1987). Migration and Mental Health: An Empirical Test of Depression Risk Factors among Immigrant Mexican Women. International Migration Review, 21(3):512-530.

Vega W.A., Kolody B., Aguilar-Gaxiola S., Alderete E., Catalano R. and Caraveo-Anduaga J. (1998). Lifetime Prevalence of DSM-III-R Psychiatric Disorders Among Urban and Rural Mexican Americans in California. Archives of General Psychiatry, 55: 771-778.

von Hippel P.T. (2007). Regression with Missing Y's: an Improved Strategy for Analyzing Multiply Imputed Data. Sociological Methodology, 37(1): 83-117.

Ying Y.W. (1996). Immigration Satisfaction of Chinese Americans: An Empirical Examination. Journal of Community Psychology, 24: 3-16.

Zimmermann A.C. and Easterlin R.A. (2006). Happily Ever after? Cohabitation, Marriage, Divorce, and Happiness in Germany. Population and Development Review,32(3): 511-528. 


\section{Tables}

Table 1. Descriptive statistics of migrants before and after the move, by municipality migration status, all three cohorts and final education levels combined

\begin{tabular}{|c|c|c|c|c|c|c|}
\hline & \multicolumn{6}{|c|}{ Statistics before the move (1999) } \\
\hline & All migrants & $\begin{array}{c}\text { Non-work } \\
\text { migrants }\end{array}$ & $\begin{array}{c}\text { Work } \\
\text { migrants }\end{array}$ & $\begin{array}{c}\text { Reason of } \\
\text { move } \\
\text { missing }\end{array}$ & Nonmigrants & Total \\
\hline & Mean & Mean & Mean & Mean & Mean & Mean \\
\hline Mean life satisfaction & 3.85 & 3.87 & 3.79 & 3.96 & 3.97 & 3.92 \\
\hline Mean disposable income & 107.54 & 106.11 & 103.18 & 126.49 & 113.8 & 111.242 \\
\hline $\begin{array}{l}\text { Mean work income } \\
\text { (with replacements) }\end{array}$ & 113.28 & 113.38 & 99.16 & 153.52 & 131.92 & 124.301 \\
\hline Mean satisfaction with house & 3.54 & 3.57 & 3.42 & 3.75 & 3.79 & 3.69 \\
\hline Mean economic satisfaction & 3.09 & 3.07 & 3.08 & 3.18 & 3.13 & 3.11 \\
\hline Mean satisfaction with occupation & 3.88 & 3.85 & 3.98 & 3.72 & 3.76 & 3.81 \\
\hline Mean years of education & 12.91 & 12.82 & 13.26 & 12.27 & 12.24 & 12.51 \\
\hline Percent male & $45.70 \%$ & $43.00 \%$ & $50.00 \%$ & $45.50 \%$ & $43.80 \%$ & $44.60 \%$ \\
\hline Percent married & $7.50 \%$ & $9.30 \%$ & $5.90 \%$ & $3.90 \%$ & $17.20 \%$ & $13.20 \%$ \\
\hline Percent divorced/widowed & $1.10 \%$ & $1.20 \%$ & $0.50 \%$ & $2.60 \%$ & $1.00 \%$ & $1.00 \%$ \\
\hline Percent studying & $12.10 \%$ & $11.90 \%$ & $15.70 \%$ & $2.60 \%$ & $4.90 \%$ & $7.90 \%$ \\
\hline $\begin{array}{l}\text { Percent of professional, higher non- } \\
\text { manual and self-employed }\end{array}$ & $10.60 \%$ & $9.71 \%$ & $11.90 \%$ & $10.40 \%$ & $7.30 \%$ & $8.70 \%$ \\
\hline Percent from 1976 cohort & $47.30 \%$ & $45.30 \%$ & $53.20 \%$ & $39.00 \%$ & $30.40 \%$ & $37.30 \%$ \\
\hline Percent from 1972 cohort & $32.50 \%$ & $34.00 \%$ & $27.90 \%$ & $39.00 \%$ & $35.90 \%$ & $34.50 \%$ \\
\hline \multirow[t]{3}{*}{ Percent from 1968 cohort } & $20.20 \%$ & $20.60 \%$ & $18.90 \%$ & $22.10 \%$ & $33.70 \%$ & $28.20 \%$ \\
\hline & \multicolumn{6}{|c|}{ Statistics after the move (2009) } \\
\hline & Mean & Mean & Mean & Mean & Mean & Mean \\
\hline Mean life satisfaction & 4 & 3.98 & 4 & 4.15 & 3.92 & 3.96 \\
\hline Mean disposable income & 211.48 & 200.388 & 222.34 & 229.72 & 201.17 & 205.39 \\
\hline $\begin{array}{l}\text { Mean work income } \\
\text { (with replacements) }\end{array}$ & 260.11 & 238.25 & 287.14 & 279.82 & 242.05 & 249.43 \\
\hline Mean satisfaction with house & 3.97 & 4.03 & 3.81 & 4.18 & 3.99 & 3.98 \\
\hline Mean economic satisfaction & 3.58 & 3.47 & 3.68 & 3.75 & 3.49 & 3.53 \\
\hline Mean satisfaction with occupation & 3.97 & 3.93 & 4.03 & 3.99 & 3.91 & 3.94 \\
\hline Mean years of education & 14.39 & 14.204 & 15.02 & 13.42 & 13.19 & 13.68 \\
\hline Percent male & $45.70 \%$ & $43.00 \%$ & $50.00 \%$ & $45.50 \%$ & $43.80 \%$ & $44.60 \%$ \\
\hline Percent married & $45.60 \%$ & $48.80 \%$ & $41.00 \%$ & $44.20 \%$ & $45.20 \%$ & $45.30 \%$ \\
\hline Percent divorced & $3.90 \%$ & $4.10 \%$ & $3.60 \%$ & $3.90 \%$ & $5.80 \%$ & $5.00 \%$ \\
\hline Percent studying & $0.50 \%$ & $0.90 \%$ & $0.00 \%$ & $0.00 \%$ & $0.50 \%$ & $0.50 \%$ \\
\hline $\begin{array}{l}\text { Percent of professional, higher non- } \\
\text { manual and self-employed }\end{array}$ & $32.10 \%$ & $27.90 \%$ & $42.00 \%$ & $20.60 \%$ & $17.20 \%$ & $23.30 \%$ \\
\hline Percent from 1976 cohort & $47.30 \%$ & $45.30 \%$ & $53.20 \%$ & $39.00 \%$ & $30.40 \%$ & $37.30 \%$ \\
\hline Percent from 1972 cohort & $32.50 \%$ & $34.00 \%$ & $27.90 \%$ & $39.00 \%$ & $35.90 \%$ & $34.50 \%$ \\
\hline Percent from 1968 cohort & $20.20 \%$ & $20.60 \%$ & $18.90 \%$ & $22.10 \%$ & $33.70 \%$ & $28.20 \%$ \\
\hline
\end{tabular}




\begin{tabular}{|c|c|c|c|c|c|c|c|c|}
\hline \multirow[b]{2}{*}{ Move pattern } & \multicolumn{2}{|c|}{1976 cohort } & \multicolumn{2}{|c|}{1972 cohort } & \multicolumn{2}{|c|}{1968 cohort } & \multicolumn{2}{|c|}{ All cohorts } \\
\hline & $\mathrm{N}$ & $\%$ & $N$ & $\%$ & $\mathrm{~N}$ & $\%$ & $\mathrm{~N}$ & $\%$ \\
\hline Within urban counties & 32 & 5.45 & 20 & 3.68 & 9 & 2.03 & 61 & 3.88 \\
\hline Within rural counties & 53 & 9.03 & 24 & 4.42 & 8 & 1.81 & 85 & 5.40 \\
\hline Urban to rural county & 22 & 3.75 & 18 & 3.31 & 22 & 4.97 & 62 & 3.94 \\
\hline Rural to urban county & 74 & 12.61 & 35 & 6.45 & 17 & 3.84 & 126 & 8.01 \\
\hline Non-county migrant & 123 & 20.95 & 112 & 20.63 & 74 & 16.70 & 309 & 19.64 \\
\hline Non-migrant & 283 & 48.21 & 334 & 61.51 & 313 & 70.65 & 930 & 59.12 \\
\hline \multirow[t]{2}{*}{ Total } & 587 & 100.00 & 543 & 100.00 & 443 & 100.00 & 1573 & 100.00 \\
\hline & \multicolumn{2}{|c|}{ Work migrants } & \multicolumn{2}{|c|}{ Non-work migrants } & \multicolumn{2}{|c|}{ All migrants } & \multicolumn{2}{|c|}{ Total population } \\
\hline Move pattern & $\mathrm{N}$ & $\%$ & $\mathrm{~N}$ & $\%$ & $\mathrm{~N}$ & $\%$ & $\mathrm{~N}$ & $\%$ \\
\hline Within urban counties & 29 & 13.06 & 32 & 9.3 & 61 & 9.49 & 61 & 3.88 \\
\hline Within rural counties & 37 & 16.67 & 47 & 13.66 & 85 & 13.22 & 85 & 5.4 \\
\hline Urban to rural county & 20 & 9.01 & 41 & 11.92 & 62 & 9.64 & 62 & 3.94 \\
\hline Rural to urban county & 62 & 27.93 & 63 & 18.31 & 126 & 19.60 & 126 & 8.01 \\
\hline Non-county migrant & 74 & 33.33 & 161 & 46.8 & 309 & 48.06 & 309 & 19.64 \\
\hline Non-migrant & & & & & & & 930 & 59.12 \\
\hline Total & 222 & 100 & 344 & 100 & 643 & 100 & 1,573 & 100 \\
\hline
\end{tabular}

\begin{tabular}{|c|c|c|c|c|c|c|c|c|c|c|c|c|c|c|c|}
\hline & (1) & (9) & (9) & (a) & (5) & (c) & (7) & (0) & (0) & (10) & (11) & (10) & (19) & & (15) \\
\hline & \multicolumn{4}{|c|}{ LM transitions } & \multicolumn{4}{|c|}{ No LM transitions } & \multicolumn{4}{|c|}{ Whole population } & \multicolumn{3}{|c|}{$\begin{array}{l}\text { LM transition - } \\
\text { No LM transition }\end{array}$} \\
\hline & & \multicolumn{3}{|c|}{ Mean LS } & & \multicolumn{3}{|c|}{ Mean LS } & & \multicolumn{3}{|c|}{ Mean LS } & \multicolumn{3}{|c|}{ Mean LS } \\
\hline & $\mathrm{N}$ & 1999 & 2009 & Change & $\mathrm{N}$ & 1999 & 2009 & Change & $\mathrm{N}$ & 1999 & 2009 & Change & 1999 & 2009 & Change \\
\hline $\begin{array}{l}\text { Work } \\
\text { migrants }\end{array}$ & 121 & 3.76 & 4.06 & 0.30 & 101 & 3.82 & 3.92 & 0.10 & 222 & 3.79 & 4.00 & 0.21 & -0.06 & 0.14 & 0.20 \\
\hline $\begin{array}{l}\text { Non- } \\
\text { work } \\
\text { migrants }\end{array}$ & 146 & 3.81 & 4.03 & 0.21 & 196 & 3.90 & 3.94 & 0.04 & 344 & 3.87 & 3.98 & 0.11 & -0.09 & 0.08 & 0.17 \\
\hline $\begin{array}{l}\text { All } \\
\text { migrants }\end{array}$ & 294 & 3.80 & 4.04 & 0.24 & 344 & 3.89 & 3.98 & 0.09 & 643 & 3.85 & 4.00 & 0.15 & -0.09 & 0.06 & 0.15 \\
\hline $\begin{array}{l}\text { Non- } \\
\text { migrants }\end{array}$ & 264 & 3.89 & 3.92 & 0.03 & 654 & 4.01 & 3.93 & -0.08 & 930 & 3.97 & 3.92 & -0.05 & -0.11 & -0.01 & 0.11 \\
\hline Total & 558 & 3.84 & 3.98 & 0.14 & 998 & 3.97 & 3.95 & -0.02 & 1573 & 3.92 & 3.96 & 0.03 & -0.12 & 0.04 & 0.16 \\
\hline
\end{tabular}




\begin{tabular}{|c|c|c|c|c|c|c|}
\hline \multicolumn{7}{|c|}{$\begin{array}{l}\text { Table 4. OLS and MI ICE regressions: Life satisfaction as dependent variable, } \\
\text { regressed on migrant dummy (pooled and by reason to move) - non-migrants as } \\
\text { reference group - with additional control variables }\end{array}$} \\
\hline & \multicolumn{6}{|c|}{ Life satisfaction } \\
\hline & (1) & (2) & (3) & (4) & (5) & (6) \\
\hline & & & \multicolumn{2}{|c|}{ OLS } & \multicolumn{2}{|c|}{ MI ICE } \\
\hline \multirow[t]{2}{*}{ all migrants } & 0.196 & 0.174 & & & & \\
\hline & $(3.64)^{\star \star}$ & $(3.12)^{\star \star}$ & & & & \\
\hline \multirow[t]{2}{*}{ work migrant } & & & 0.26 & 0.222 & 0.262 & 0.230 \\
\hline & & & $(3.34)^{\star \star}$ & $(2.76)^{\star \star}$ & $(3.25)^{\star \star}$ & $(2.81)^{\star \star}$ \\
\hline \multirow[t]{2}{*}{ non-work migrant } & & & 0.151 & 0.132 & 0.160881 & 0.145 \\
\hline & & & $(2.30)^{\star}$ & $(1.97)^{\star}$ & $(2.53)^{\star}$ & $(2.25)^{\star}$ \\
\hline \multirow[t]{2}{*}{ married FD } & & 0.006 & & -0.006 & & 0.006 \\
\hline & & $(0.11)$ & & $(0.1)$ & & $(0.11)$ \\
\hline \multirow[t]{2}{*}{ divorced/widowed FD } & & -0.055 & & -0.08 & & -0.057 \\
\hline & & $(0.37)$ & & $(0.51)$ & & $(0.43)$ \\
\hline \multirow[t]{2}{*}{ Im_transition } & & 0.116 & & 0.132 & & 0.112 \\
\hline & & $(2.05)^{\star}$ & & $(2.23)^{\star}$ & & $(1.99)^{*}$ \\
\hline \multirow{2}{*}{ Constant } & -0.039 & -0.064 & -0.037 & -0.06 & -0.040 & -0.065 \\
\hline & $(0.6)$ & $(0.92)$ & $(0.55)$ & $(0.83)$ & $(0.63)$ & $(0.94)$ \\
\hline Observations & 1541 & 1526 & 1467 & 1454 & 1541 & 1526 \\
\hline R-squared & 0.03 & 0.03 & 0.03 & 0.04 & & \\
\hline \multicolumn{7}{|c|}{ Robust t statistics in parentheses } \\
\hline \multicolumn{7}{|c|}{ + significant at $10 \% ;{ }^{*}$ significant at $5 \%$; ** significant at $1 \%$} \\
\hline \multicolumn{7}{|c|}{ All regressions include county controls corresponding to $D_{c o}$ and $\left(D_{c 1}-D_{c o}\right)$ from model $(2 b)$. } \\
\hline
\end{tabular}




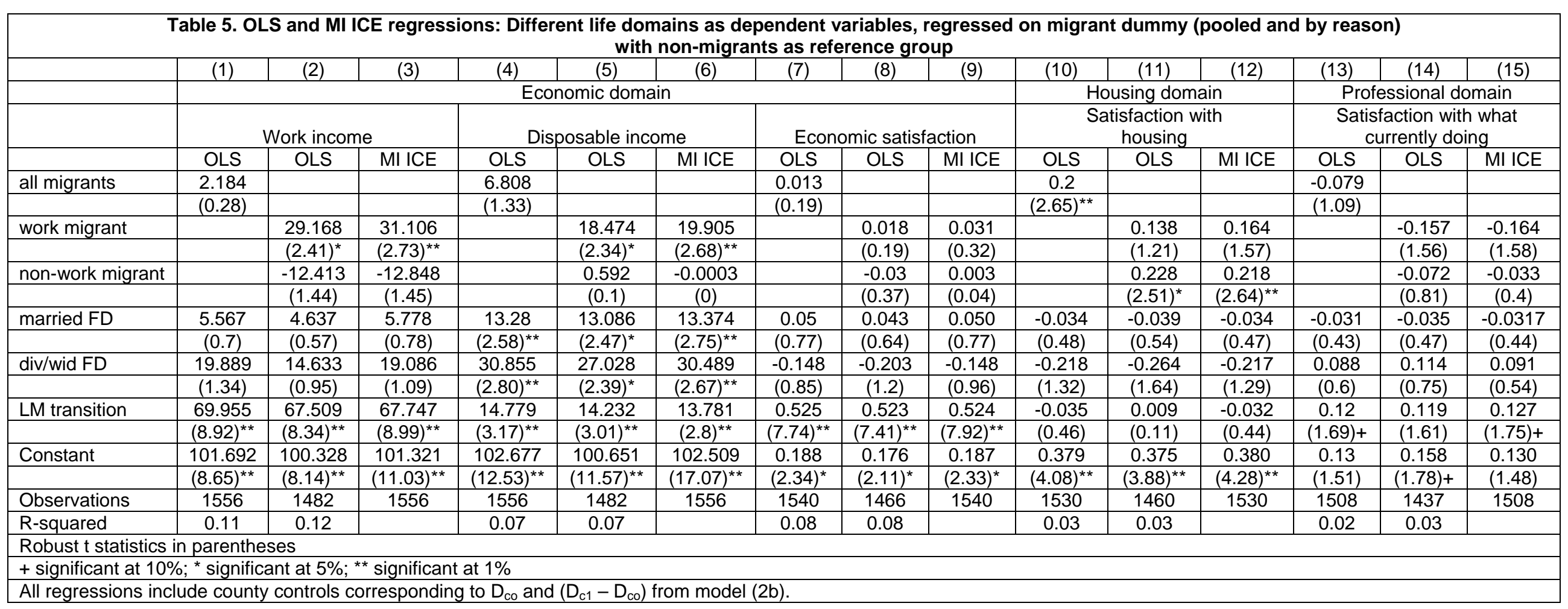




\begin{tabular}{|c|c|c|c|c|c|c|c|c|c|}
\hline \multicolumn{10}{|c|}{$\begin{array}{c}\text { Table 6. Occupational mobility in 1999-2009 between low/middle/and high life satisfaction } \\
\text { occupation categories, by migrant status and reason to move }\end{array}$} \\
\hline \multicolumn{5}{|c|}{ Non-migrant } & \multicolumn{5}{|c|}{ All migrants } \\
\hline \multicolumn{5}{|c|}{ occupation group in 2009} & & \multicolumn{4}{|c|}{ occupation group in 2009} \\
\hline $\begin{array}{l}\text { occup group } \\
\text { in } 1999\end{array}$ & $\begin{array}{l}\text { Low } \\
\text { LS }\end{array}$ & $\begin{array}{l}\text { Med } \\
\text { LS }\end{array}$ & $\begin{array}{l}\text { High } \\
\text { LS }\end{array}$ & Total & $\begin{array}{l}\text { occup group } \\
\text { in } 1999\end{array}$ & $\begin{array}{l}\text { Low } \\
\text { LS }\end{array}$ & $\begin{array}{l}\text { Med } \\
\text { LS }\end{array}$ & $\begin{array}{l}\text { High } \\
\text { LS }\end{array}$ & Total \\
\hline $\begin{array}{l}\text { Low } \\
\text { LS }\end{array}$ & 1.51 & 15.58 & 6.98 & 24.07 & $\begin{array}{l}\text { Low } \\
\text { LS }\end{array}$ & 1.31 & 22.00 & 17.41 & 40.72 \\
\hline $\begin{array}{l}\text { Med } \\
\text { LS }\end{array}$ & 2.79 & 55.81 & 6.28 & 64.88 & $\begin{array}{l}\text { Med } \\
\text { LS }\end{array}$ & 2.79 & 36.78 & 8.21 & 47.78 \\
\hline $\begin{array}{l}\text { High } \\
\text { LS }\end{array}$ & 0.70 & 5.93 & 4.42 & 11.05 & $\begin{array}{l}\text { High } \\
\text { LS }\end{array}$ & 0.00 & 4.76 & 6.73 & 11.49 \\
\hline Total & 5.00 & 77.33 & 17.67 & 100.00 & Total & 4.11 & 63.55 & 32.35 & 100.00 \\
\hline \multicolumn{5}{|c|}{ Work migrants } & \multicolumn{5}{|c|}{ Non-work migrants } \\
\hline \multicolumn{5}{|c|}{ occupation group in 2009} & & \multicolumn{4}{|c|}{ occupation group in 2009} \\
\hline $\begin{array}{l}\text { occup group } \\
\text { in } 1999\end{array}$ & $\begin{array}{l}\text { Low } \\
\text { LS }\end{array}$ & $\begin{array}{l}\text { Med } \\
\text { LS }\end{array}$ & $\begin{array}{l}\text { High } \\
\text { LS }\end{array}$ & Total & $\begin{array}{l}\text { occup group } \\
\text { in } 1999\end{array}$ & $\begin{array}{c}\text { Low } \\
\text { LS }\end{array}$ & $\begin{array}{l}\text { Med } \\
\text { LS }\end{array}$ & $\begin{array}{l}\text { High } \\
\text { LS }\end{array}$ & Total \\
\hline $\begin{array}{l}\text { Low } \\
\text { LS }\end{array}$ & 0.93 & 25.12 & 26.98 & 53.02 & $\begin{array}{l}\text { Low } \\
\text { LS }\end{array}$ & 1.84 & 21.47 & 13.19 & 36.50 \\
\hline $\begin{array}{l}\text { Med } \\
\text { LS }\end{array}$ & 1.86 & 25.58 & 7.91 & 35.35 & $\begin{array}{l}\text { Med } \\
\text { LS }\end{array}$ & 3.37 & 40.80 & 7.98 & 52.15 \\
\hline $\begin{array}{l}\text { High } \\
\text { LS }\end{array}$ & 0.00 & 4.19 & 7.44 & 11.63 & $\begin{array}{l}\text { High } \\
\text { LS }\end{array}$ & 0.00 & 4.29 & 7.06 & 11.35 \\
\hline Total & 2.79 & 54.88 & 42.33 & 100.00 & Total & 5.21 & 66.56 & 28.22 & 100.00 \\
\hline
\end{tabular}




\section{Appendix A. Attrition in the Young Adult Panel Study}

Given its longitudinal nature, the YAPS survey faces the inevitable problem of attrition. Out of the 2820 individuals first interviewed in 1999, only 1575 were successfully re-interviewed in 2009. This generated an attrition rate of $44 \%$ over the period of 10 years, similar to the rates observed in other longitudinal surveys carried out in developed countries such as the United States (Becketti et al 1998, Abraham 2006). The high non-response in the YAPS gives rise to concerns about possible biases associated with attrition. In what follows, first, the main characteristics at baseline of the people who attrit (are not re-interviewed in 2009) and who do not attrit are compared. Then, two main problems related to attrition are discussed: selectivity on migration, and selectivity on unobserved time-varying characteristics related to the changes in the dependent variables of the study.

At baseline, attritors have generally lower income ${ }^{8}$, lower economic satisfaction, and less years of education, then the people who are interviewed in both 1999 and 2009. Also, they are more likely to be male, young, and have Swedish background (Table A1). The first series of characteristics related to income and education, stands in opposition to what has been observed in previous studies in both developing (Thomas et al 2001 and 2011) and developed countries (Hausman 1979, Becketti et al 1998), where attrition was found to have a positive association with higher income and education levels at baseline. This, however, is probably due to the specific design of this survey which targets only young adults (ages 22 to 30 in 1999). Given the young age distribution of the YAPS respondents, some of those interviewed in 1999 (especially the youngest ones) could be expected to be still studying, and therefore have lower income and economic satisfaction. Given that young people are more likely to leave the survey, a higher percentage of attritors would have not achieved their final levels of education in 1999, lowering the average education level of this group, as well as their income and economic satisfaction.

The relationship between the birth cohort and attrition is similar to that observed in previous literature, with younger cohorts being more likely to attrit in subsequent interviews. The difference in the attrition rates of people with Swedish and non-Swedish background may be related to previous findings that early life experience and parent characteristics are related to attrition (Thomas et al 2011). Interestingly, higher levels of attrition are not associated with

\footnotetext{
${ }^{8}$ The income variable used here is self-reported income in 1999, and is different from the Register data used in the study. The Register data could not be used to analyze the problem of attrition, as it is only available for the people who are interviewed in 2009 - consequently, it is only available for non-attritors.
} 
more hours worked per week, as could be expected if busy people were less likely to be reinterviewed. Previous studies conducted with surveys from the United States have found that non-contact is in fact associated with longer work times, though the same did not hold for refusals, with refusal rates showing no association with work time (Abraham 2006).

Attrition in the YAPS survey could present a big problem for the present study if it was selective on migration, especially given that the main questions are related to comparisons of migrants and non-migrants before and after the move. Past research has found that attrition in longitudinal surveys may, in fact, be selective on migration. This problem arises especially in the case of surveys performed in developing countries (Thomas et al 2003 and 2010), as in developed countries non-response is mostly associated with refusals. Still, Abraham and coauthors (2006) find that non-contact rates may also be high in developed countries, as documented by their observations about the American Time Use Survey.

The problem of attrition due to migration should be lessened in the YAPS due to the access of the employees of Statistics Sweden, who were in charge of the data collection, to the Swedish Register records. The Register consists of data collected by the Swedish Tax Agency and includes specific information about current place of residence for all individuals. Access to this information could facilitate the task of following the people who had moved between the surveys, making it considerably easier than what it is in countries with less precise demographic information on their inhabitants.

A comparison of non-contact versus refusal rates in the YAPS could be informative, as non-response associated with non-contact may be more related to trouble finding a person who has moved. Unfortunately, the YAPS survey was performed by mail, and so no information of non-contact versus refusal rates was collected. Previously it has been found that attrition is, in general, associated with similar demographic characteristics across different surveys (Zabel 1998). Therefore a comparison of the characteristics of attritors in the YAPS to the characteristics of people who were not re-interviewed due to non-contact in other surveys in developed countries could be insightful.

Abraham and co-authors analyze attrition in a survey with relatively high non-contact rates (the American Time Use Survey) for a developed country (Abraham et al 2006). They find that non-contact is associated with being single, working longer hours, and being a high school graduate. In the YAPS, the proportion of people married and the hours worked at baseline are not 
statistically different for attritors and non-attritors. Moreover, attritors have significantly less years of education, which is the opposite of the association between education and non-contact found by Abraham and co-authors. If the same associations between non-contact and demographic characteristics hold for Sweden as for United States, this could imply that a big proportion of attrition in the YAPS is due to refusal. Still, it is not clear that Swedish attrition should follow the same patterns as those observed in studies from other countries, and so the previous implication is definitely not certain.

An indirect test of how selective attrition may be on a given characteristic used by previous literature consists of comparing the observed sample of population from the survey to a similar sample of general population (Groves 2006). Using this idea, a test of selectivity on migration in the YAPS could be performed by comparing rates of mobility of the people interviewed in both years of the survey, to the rates of mobility of the general population of Sweden. Specifically, the percentages of people who changed municipalities between 1999 and 2009, by cohort, from the YAPS and the general population are compared. For every cohort, the mobility of the general population is slightly above that of the non-attritors from YAPS, with the difference between the two populations being highest for the 1976 cohort. For all cohorts combined, the difference in the migration proportions between the general population and the YAPS is 3\% (44\% for general population and $41 \%$ for YAPS). This difference implies that, though selectivity on migration might have certainly taken place in the YAPS survey, the magnitude of this problem should not be very big.

The second reasons why attrition may bias the results of the study, is if it is selective on unobserved time-varying characteristics that are associated with either changes in life satisfaction or any of the other dependent variables used. Based on the analysis of baseline characteristics it appears that, in levels, attrition is not highly associated with most of the dependent variables used, with income and economic satisfaction being the two exceptions (Table A1). To further analyze the relationship between attrition and the dependent variables, a test from previous literature (Fitzgerald 1997) is used. This test employs regressions of the main dependent variables at baseline on subsequent attrition and control variables, to check for the significance of attrition. If attrition is in fact a problem, then its coefficient in such a regression should be significant. 
Attrition is not significant, both with and without additional control variables, for life satisfaction, satisfaction with housing, satisfaction with partner, and satisfaction with what the person is currently doing. This indicates that, most likely, attrition is not selective on these variables. Controlling for the personal characteristics that are accounted for in the main regressions ${ }^{9}$, attrition loses its significance in the income regression, and remains statistically significant at 5\% only for economic satisfaction (Table A3).

The dependent variables on which the attrition tests are run are not the same as the ones used in the study. The dependent variables used in the main part of the paper are presented in first difference, whereas the ones employed in the tests are in levels. The first difference variables should be more robust to possible selection problems, as they implicitly control for any fixed characteristics of the respondents that could be related to their subsequent non-response. Still, previous research has shown that attrition could also be related to time-varying unobserved characteristics that could bias the results of a first-difference regression (Thomas et al 2011).

Since attritors are not interviewed in 2009 , it is impossible to check whether their changes in the variables of interest are different from those of the non-attritors. What can be done, however, is to compare the changes in a clue variable for the sample of respondents from the YAPS interviewed in both 1999 and 2009, to the changes in the same variable for the general population. This comparison is carried out for income changes (Table A4). There are two main reasons to use income for this test. First, disposable income is readily available from the Swedish Register for both, the YAPS sample, and the general population. Second, attrition has been specifically found to be selective on changes in returns to human capital, such as education (Thomas et al 2011), which could possibly be reflected in changes in disposable income.

For both migrants and non-migrants observed in the YAPS survey in 1999 and 2009, the changes in disposable income are slightly above those of the general population. ${ }^{10}$ Because the present study is based on the comparison of migrants versus non-migrants, one may be especially interested in comparing the difference in changes in income for these two groups for the YAPS sample and the general population. For the sample of non-attritors from YAPS, the difference

\footnotetext{
${ }^{9}$ Note that, though time invariant characteristics (such as gender or having a Swedish background) are not used as controls in the main regressions, they are still being taken into account, as the first-difference regressions used automatically control for individual fixed effects. Also, these regression is unable to control for labor market transitions, as the year in which highest education level was achieved is unavailable for attritors. Instead, occupational controls are included.

${ }^{10}$ The general population encompasses all inhabitants of Sweden born in the 1968, 1972 and 1976 cohorts for whom Register information was available in 1999 and 2009.
} 
between changes in income for migrants and non-migrants is $21800 \mathrm{SEK}$; the difference between the migrant groups for the general population is 26500 SEK (Table A4). The closeness between these two differences is reassuring.

Because of the high levels of attrition in the YAPS survey, concerns with possible bias may certainly arise. Given the previous analysis, selective attrition on migration, though possible, appears to be generally small in magnitude. The first-difference regression analysis used in the study allows to control for all time invariant unobserved characteristics that could be related to both attrition and the variables of interest. Though the possibility of time varying unobserved characteristics related to attrition remains, a comparison of the difference for the two migrant groups in the changes in disposable income for the YAPS sample and the general population, provides reassuring results, with the two differences being quite close in magnitude. In conclusion, the results of the analysis performed in this section provide reassurance that the possible attirition bias in the survey should not have a very strong effect on the main results of the study. 


\begin{tabular}{|c|c|c|c|c|c|c|}
\hline \multicolumn{7}{|c|}{$\begin{array}{l}\text { Table A1. Comparison of the characteristics at baseline (1999) of surveyed people who } \\
\text { consequently attrit (not interviewed in 2009) and do not attrit (interviewed in 2009) }\end{array}$} \\
\hline & \multicolumn{2}{|c|}{ Complete sample } & \multicolumn{2}{|c|}{ Non-attritors } & \multicolumn{2}{|c|}{ Attritors } \\
\hline & $\mathrm{N}$ & Mean, \% & $\mathrm{N}$ & Mean & $\mathrm{N}$ & Mean \\
\hline Life satisfaction & 2785 & 3.91 & 1560 & 3.92 & 1225 & 3.9 \\
\hline $\begin{array}{l}\text { Self reported income } \\
\text { (in } 1000 \text { SEK) }\end{array}$ & 2800 & 101 & 1573 & 104 & 1227 & 97 \\
\hline Economic satisfaction & 2789 & 3.05 & 1564 & 3.11 & 1225 & 2.97 \\
\hline Satisfaction with housing & 2776 & 3.7 & 1556 & 3.69 & 1220 & 3.73 \\
\hline Satisfaction with partner & 2075 & 4.47 & 1159 & 4.45 & 916 & 4.49 \\
\hline $\begin{array}{l}\text { Satisfaction with } \\
\text { current occupation }\end{array}$ & 2751 & 3.78 & 1551 & 3.81 & 1200 & 3.76 \\
\hline Educ level 1999** & 2782 & 11.98 & 1565 & 12.19 & 1217 & 11.71 \\
\hline Hours worked per week & 2014 & 37.47 & 1132 & 37.79 & 882 & 37.06 \\
\hline$\%$ Male & 1320 & $46.80 \%$ & 702 & $44.57 \%$ & 618 & $49.64 \%$ \\
\hline \% Studying & 208 & $7.71 \%$ & 121 & $7.94 \%$ & 87 & $7.40 \%$ \\
\hline \% Cohort 1976 (age 22) & 1107 & $39.30 \%$ & 589 & $37.40 \%$ & 518 & $41.60 \%$ \\
\hline \% Cohort 1972 (age 26) & 973 & $34.50 \%$ & 543 & $34.50 \%$ & 430 & $34.50 \%$ \\
\hline \% Cohort 1968 (age 30) & 740 & $26.20 \%$ & 443 & $28.10 \%$ & 297 & $23.90 \%$ \\
\hline$\%$ Married & 393 & $14 \%$ & 208 & $13.20 \%$ & 185 & $15.10 \%$ \\
\hline$\%$ Swedish background & 2283 & $80.96 \%$ & 1336 & $84.83 \%$ & 947 & $76.06 \%$ \\
\hline $\begin{array}{l}\% \text { Polish or Turkish } \\
\text { background }\end{array}$ & 537 & $19.04 \%$ & 239 & $15.17 \%$ & 298 & $23.94 \%$ \\
\hline \multicolumn{7}{|c|}{$\begin{array}{l}\text { Bold values imply that the mean or } \% \text { for attritors and non-attritors are statistically different at } 5 \% \\
\text { significance level. }\end{array}$} \\
\hline
\end{tabular}

\begin{tabular}{|c|c|c|c|}
\hline \multicolumn{4}{|c|}{$\begin{array}{c}\text { Table A2. Proportion of mobility by cohort: } \\
\text { general population vs. YAPS non-attritors }\end{array}$} \\
\hline & \multicolumn{3}{|c|}{$\%$ Migrants } \\
\hline Cohort & $\begin{array}{c}\text { General Pop. } \\
\text { (Register) }\end{array}$ & $\begin{array}{c}\text { YAPS } \\
\text { non-attritors }\end{array}$ & Difference \\
\hline 1968 & $31.16 \%$ & $29.24 \%$ & $1.92 \%$ \\
\hline 1972 & $44.04 \%$ & $38.61 \%$ & $5.43 \%$ \\
\hline 1976 & $57.65 \%$ & $51.35 \%$ & $6.31 \%$ \\
\hline Total & $43.63 \%$ & $40.65 \%$ & $2.98 \%$ \\
\hline
\end{tabular}




\begin{tabular}{|c|c|c|c|c|c|c|c|c|c|c|}
\hline & \multicolumn{10}{|c|}{$\begin{array}{c}\text { Table A3. Indirect test for attrition bias -- } \\
\text { OLS regressions of variables of interest on future attrition and control variables }\end{array}$} \\
\hline & \multicolumn{2}{|c|}{$\begin{array}{l}\text { Life } \\
\text { satisfaction }\end{array}$} & \multicolumn{2}{|c|}{$\begin{array}{l}\text { Self-repored } \\
\text { income }\end{array}$} & \multicolumn{2}{|c|}{$\begin{array}{l}\text { Economic } \\
\text { satisfaction }\end{array}$} & \multicolumn{2}{|c|}{$\begin{array}{l}\text { Sat with } \\
\text { housing }\end{array}$} & \multicolumn{2}{|c|}{$\begin{array}{l}\text { Sat with what } \\
\text { currently doing }\end{array}$} \\
\hline attrit99_09 & -0.028 & 0.006 & -7.711 & -3.505 & -0.139 & -0.099 & 0.043 & 0.058 & -0.053 & -0.006 \\
\hline & $(0.79)$ & $(0.17)$ & $(2.57)^{\star}$ & $(1.44)$ & $(3.19)^{\star \star}$ & $(2.33)^{\star}$ & (1) & $(1.32)$ & $(1.22)$ & $(0.14)$ \\
\hline male & & -0.157 & & 16.516 & & -0.078 & & 0.118 & & 0.007 \\
\hline & & $(4.19)^{\star \star}$ & & $(6.39)^{\star \star}$ & & $(1.33)$ & & $(1.91)+$ & & $(0.13)$ \\
\hline swedish & & 0.174 & & 5.319 & & 0.109 & & -0.149 & & -0.051 \\
\hline & & $(3.57)^{\star \star}$ & & $(1.75)+$ & & $(2.49)^{\star}$ & & $(3.28)^{\star \star}$ & & $(1.18)$ \\
\hline married & & 0.247 & & 3.494 & & 0.186 & & 0.146 & & 0.05 \\
\hline & & $(4.64)^{\star \star}$ & & $(0.92)$ & & $(2.97)^{\star \star}$ & & $(2.38)^{\star}$ & & $(0.77)$ \\
\hline $\begin{array}{l}\text { divorced/ } \\
\text { widowed }\end{array}$ & & -0.172 & & -21.987 & & -0.459 & & 0.024 & & -0.287 \\
\hline & & $(1.33)$ & & $(2.80)^{\star \star}$ & & $(2.66)^{\star \star}$ & & $(0.14)$ & & $(1.56)$ \\
\hline $\begin{array}{l}\text { service } \\
\text { production }\end{array}$ & & -0.011 & & -21.777 & & -0.223 & & -0.074 & & -0.103 \\
\hline & & $(0.17)$ & & $(5.28)^{\star \star}$ & & $(2.75)^{\star \star}$ & & $(0.91)$ & & $(1.23)$ \\
\hline $\begin{array}{l}\text { assistant } \\
\text { non-manual }\end{array}$ & & -0.06 & & -18.736 & & 0.026 & & -0.178 & & 0.053 \\
\hline & & $(0.8)$ & & $(3.69)^{\star \star}$ & & $(0.29)$ & & $(1.89)+$ & & $(0.58)$ \\
\hline $\begin{array}{l}\text { intermediate } \\
\text { non-manual }\end{array}$ & & -0.027 & & -23.466 & & 0.199 & & -0.136 & & 0.373 \\
\hline & & $(0.41)$ & & $(4.77)^{\star \star}$ & & $(2.55)^{\star}$ & & $(1.69)+$ & & $(4.85)^{\star \star}$ \\
\hline $\begin{array}{l}\text { professional/ } \\
\text { higher non- } \\
\text { manual/ } \\
\text { self-employed }\end{array}$ & & 0.01 & & -29.516 & & 0.334 & & -0.154 & & 0.443 \\
\hline & & $(0.13)$ & & $(4.09)^{\star \star}$ & & $(3.80)^{\star \star}$ & & $(1.69)+$ & & $(4.99)^{\star \star}$ \\
\hline $\begin{array}{l}\text { executives/ } \\
\text { entrepreneurs } \\
\text { /farmers }\end{array}$ & & 0.169 & & -20.453 & & 0.344 & & 0.082 & & 0.596 \\
\hline & & $(1.66)+$ & & $(2.25)^{\star}$ & & $(2.59)^{\star \star}$ & & $(0.62)$ & & $(5.14)^{\star \star}$ \\
\hline student & & -0.145 & & -49.467 & & -0.568 & & -0.297 & & 0.376 \\
\hline & & $(2.22)^{\star}$ & & $(11.69)^{\star \star}$ & & $(7.42)^{\star \star}$ & & $(3.87)^{\star \star}$ & & $(4.97)^{\star \star}$ \\
\hline unemployed & & -0.578 & & -41.061 & & -0.963 & & -0.395 & & -1.136 \\
\hline & & $(4.78)^{\star \star}$ & & $(6.79)^{\star \star}$ & & $(8.04)^{\star \star}$ & & $(3.04)^{\star *}$ & & $(8.32)^{\star \star}$ \\
\hline 1972 cohort & & 0.05 & & 60.699 & & -0.012 & & 0.083 & & 0.045 \\
\hline & & (1.14) & & $(21.01)^{\star \star}$ & & $(0.23)$ & & $(1.53)$ & & $(0.86)$ \\
\hline 1968 cohort & & 0.009 & & 101.118 & & 0.024 & & 0.154 & & -0.021 \\
\hline & & $(0.18)$ & & $(27.59)^{\star \star}$ & & $(0.38)$ & & $(2.42)^{\star}$ & & $(0.33)$ \\
\hline Constant & 3.924 & 3.867 & 104.267 & 70.831 & 3.111 & 3.267 & 3.686 & 3.725 & 3.808 & 3.656 \\
\hline & $(170.72)^{\star \star}$ & $(48.12)^{\star \star}$ & $(51.42)^{\star \star}$ & $(13.74)^{\star \star}$ & $(109.69)^{\star \star}$ & $(35.15)^{\star \star}$ & $(133.10)^{\star \star}$ & $(39.00)^{\star \star}$ & $(137.83)^{\star \star}$ & $(39.59)^{\star \star}$ \\
\hline Observations & 2785 & 2688 & 2800 & 2717 & 2789 & 2692 & 2776 & 2681 & 2751 & 2661 \\
\hline R-squared & 0 & 0.05 & 0 & 0.4 & 0 & 0.12 & 0 & 0.03 & 0 & 0.11 \\
\hline
\end{tabular}




\begin{tabular}{|l|c|c|c|c|c|c|}
\hline \multicolumn{7}{|c|}{$\begin{array}{c}\text { Table A4. Mean disposable income (in hundreds of SEK) from Register, whole population (1968, } \\
\text { 1972 and 1976 cohorts) and YAPS (non-attritors), by migrantion status, by year }\end{array}$} \\
\hline & \multicolumn{5}{|c|}{ Register } & \multicolumn{3}{c|}{ YAPS } \\
\hline Period & $\mathbf{1 9 9 8}$ & $\mathbf{2 0 0 7}$ & Change & $\mathbf{1 9 9 8}$ & $\mathbf{2 0 0 7}$ & Change \\
\hline Migrant & 1052 & 2262 & 1209 & 1075 & 2382 & 1307 \\
\hline Non-Migrant & 1132 & 2076 & 944 & 1138 & 2227 & 1089 \\
\hline $\begin{array}{l}\text { Both migrants and } \\
\text { non-migrants }\end{array}$ & 1097 & 2157 & 1060 & 1112 & 2290 & 1178 \\
\hline $\begin{array}{l}\text { Difference } \\
\text { migrants - } \\
\text { non-migrants }\end{array}$ & -80 & 186 & 265 & -63 & 155 & 218 \\
\hline
\end{tabular}




\section{Appendix B. Description of variables used in the study}

\begin{tabular}{|c|c|c|c|c|c|c|c|c|c|c|}
\hline \multicolumn{11}{|c|}{ Table B1. Number of people surveyed answering each question in both 99 and 09 , by migration status and reason to move, by cohort } \\
\hline & \multicolumn{5}{|c|}{ All three cohorts combined } & \multicolumn{5}{|c|}{1976 cohort } \\
\hline & $\begin{array}{c}\text { Work } \\
\text { migrants }\end{array}$ & $\begin{array}{c}\text { Non-work } \\
\text { migrants }\end{array}$ & $\begin{array}{c}\text { All } \\
\text { migrants }\end{array}$ & $\begin{array}{c}\text { Non- } \\
\text { migrants }\end{array}$ & Total & $\begin{array}{c}\text { Work } \\
\text { migrant }\end{array}$ & $\begin{array}{l}\text { Non-work } \\
\text { migrants }\end{array}$ & $\begin{array}{c}\text { All } \\
\text { migrants }\end{array}$ & $\begin{array}{c}\text { Non- } \\
\text { migrants }\end{array}$ & Total \\
\hline Life satisfaction & 218 & 338 & 630 & 911 & 1541 & 115 & 153 & 296 & 277 & 573 \\
\hline Economic satisfaction & 220 & 340 & 636 & 919 & 1555 & 117 & 152 & 299 & 281 & 580 \\
\hline Satisfaction with house & 219 & 341 & 632 & 912 & 1544 & 116 & 153 & 299 & 275 & 574 \\
\hline Satisfaction with occupation & 222 & 334 & 629 & 893 & 1522 & 118 & 153 & 301 & 275 & 576 \\
\hline Satisfaction with partner & 121 & 244 & 415 & 642 & 1057 & 59 & 103 & 177 & 167 & 344 \\
\hline Occupation group & 215 & 326 & 609 & 860 & 1469 & 115 & 148 & 289 & 266 & 555 \\
\hline Civil status & 222 & 344 & 643 & 930 & 1573 & 118 & 156 & 304 & 283 & 587 \\
\hline Education & 221 & 343 & 641 & 923 & 1564 & 117 & 155 & 302 & 280 & 582 \\
\hline Work Income & 222 & 344 & 643 & 930 & 1573 & 118 & 156 & 304 & 283 & 587 \\
\hline \multirow[t]{3}{*}{ Disposable Income } & 222 & 344 & 643 & 930 & 1573 & 118 & 156 & 304 & 283 & 587 \\
\hline & \multicolumn{5}{|c|}{1972 cohort } & \multicolumn{5}{|c|}{1968 cohort } \\
\hline & $\begin{array}{c}\text { Work } \\
\text { migrants }\end{array}$ & $\begin{array}{l}\text { Non-work } \\
\text { migrants }\end{array}$ & $\begin{array}{c}\text { All } \\
\text { migrants }\end{array}$ & $\begin{array}{c}\text { Non- } \\
\text { migrants }\end{array}$ & Total & $\begin{array}{c}\text { Work } \\
\text { migrant }\end{array}$ & $\begin{array}{l}\text { Non-work } \\
\text { migrants }\end{array}$ & $\begin{array}{c}\text { All } \\
\text { migrants }\end{array}$ & $\begin{array}{c}\text { Non- } \\
\text { migrants }\end{array}$ & Total \\
\hline Life satisfaction & 61 & 115 & 205 & 327 & 532 & 42 & 70 & 129 & 307 & 436 \\
\hline Economic satisfaction & 62 & 117 & 208 & 328 & 536 & 41 & 71 & 129 & 310 & 439 \\
\hline Satisfaction with house & 62 & 117 & 205 & 328 & 533 & 41 & 71 & 128 & 309 & 437 \\
\hline Satisfaction with occupation & 62 & 114 & 202 & 322 & 524 & 42 & 67 & 126 & 296 & 422 \\
\hline Satisfaction with partner & 34 & 84 & 141 & 237 & 378 & 28 & 57 & 97 & 238 & 335 \\
\hline Occupation group & 59 & 111 & 197 & 307 & 504 & 41 & 67 & 123 & 287 & 410 \\
\hline Civil status & 62 & 117 & 209 & 334 & 543 & 42 & 71 & 130 & 313 & 443 \\
\hline Education & 62 & 117 & 209 & 331 & 540 & 42 & 71 & 130 & 312 & 442 \\
\hline Work Income & 62 & 117 & 209 & 334 & 543 & 42 & 71 & 130 & 313 & 443 \\
\hline Disposable Income & 62 & 117 & 209 & 334 & 543 & 42 & 71 & 130 & 313 & 443 \\
\hline
\end{tabular}




\begin{tabular}{|c|c|c|c|c|c|c|c|c|c|c|c|c|}
\hline \multicolumn{13}{|c|}{ Table B2. Mean life satisfaction by occupation, by year, by migrant status } \\
\hline & \multicolumn{6}{|c|}{1999} & \multicolumn{6}{|c|}{2009} \\
\hline & \multicolumn{2}{|c|}{ migrant } & \multicolumn{2}{|c|}{ non-mig } & \multicolumn{2}{|c|}{ total } & \multicolumn{2}{|c|}{ mig } & \multicolumn{2}{|c|}{ non-mig } & \multicolumn{2}{|c|}{ total } \\
\hline & $\mathrm{n}$ & Is & $\mathrm{n}$ & Is & $\mathrm{n}$ & Is & $\mathrm{n}$ & Is & $\mathrm{n}$ & Is & $\mathrm{n}$ & Is \\
\hline Goods & 45 & 3.69 & 125 & 3.97 & 170 & 3.89 & 32 & 3.88 & 113 & 3.84 & 145 & 3.85 \\
\hline Service & 86 & 3.85 & 192 & 4.07 & 278 & 4.00 & 58 & 4.00 & 148 & 3.94 & 206 & 3.96 \\
\hline Asst & 62 & 3.95 & 107 & 3.98 & 169 & 3.97 & 64 & 4.09 & 122 & 3.93 & 186 & 3.99 \\
\hline Interm & 104 & 3.91 & 159 & 4.04 & 263 & 3.99 & 198 & 3.96 & 243 & 4.01 & 441 & 3.99 \\
\hline $\mathrm{n}-\mathrm{m} / \mathrm{self}$ & 67 & 4.03 & 66 & 4.02 & 133 & 4.02 & 198 & 4.07 & 153 & 4.00 & 351 & 4.04 \\
\hline exec/entrep/farm & 9 & 4.67 & 33 & 4.03 & 42 & 4.17 & 35 & 3.94 & 66 & 3.92 & 101 & 3.93 \\
\hline Student & 236 & 3.78 & 176 & 3.86 & 412 & 3.82 & 18 & 3.89 & 33 & 3.36 & 51 & 3.55 \\
\hline Unemp & 20 & 3.25 & 33 & 3.85 & 53 & 3.62 & 8 & 4.13 & 12 & 3.42 & 20 & 3.70 \\
\hline
\end{tabular}




\begin{tabular}{|c|c|c|}
\hline \multicolumn{3}{|c|}{ Table B3. Description of all variables used in the analysis } \\
\hline Variable & Question asked & Response categories \\
\hline migrant & $\begin{array}{l}\text { Person who, according to register data, changed municipality in the period 1999- } \\
2009 \text { (including multiple changes and return migration) }\end{array}$ & $\begin{array}{l}0 \text { - other } \\
1 \text { - migrant }\end{array}$ \\
\hline nonmigrant & $\begin{array}{l}\text { Person who, according to register data, did not change municipality in the period } \\
\text { 1999-2009 }\end{array}$ & $\begin{array}{l}0 \text { - other } \\
1 \text { - non-migrant }\end{array}$ \\
\hline work migrant & $\begin{array}{l}\text { Person who, according to register data, changed municipality in the period 1999- } \\
2009 \text { (including multiple changes and return migration) and listed "work/studies" as } \\
\text { main reason of move in the YAPS survey }\end{array}$ & $\begin{array}{l}0 \text { - other } \\
1 \text { - migrant due to work reasons }\end{array}$ \\
\hline non-work migrant & $\begin{array}{l}\text { Person who, according to register data, changed municipality in the period 1999- } \\
2009 \text { (including multiple changes and return migration) and listed something other } \\
\text { than "work/studies" as main reason of move in the YAPS survey }\end{array}$ & $\begin{array}{l}0 \text { - other } \\
1 \text { - migrant due to non-work reasons }\end{array}$ \\
\hline life satisfaction & Answer to the "life satisfaction" question from the YAPS survey & $\begin{array}{l}\text { scale } 1 \text { - } 5 \text { with } 1 \text { - very dissatisfied, and } 5= \\
\text { very satisfied }\end{array}$ \\
\hline work income & $\begin{array}{l}\text { Register information on "income from work before tax" for the years } 1998 \text { and } 2008 \\
\text { (in thousands of SEK) }\end{array}$ & \\
\hline disposable income & $\begin{array}{l}\text { Register information on "disposable income" for the years } 1998 \text { and } 2008 \\
\text { (in thousands of SEK) }\end{array}$ & \\
\hline economic satisfaction & Answer to the "economic satisfaction" question from the YAPS survey & $\begin{array}{l}\text { scale } 1 \text { - } 5 \text { with } 1 \text { - very dissatisfied, and } 5= \\
\text { very satisfied }\end{array}$ \\
\hline satisfaction with housing & Answer to the "satisfaction with housing" question from the YAPS survey & $\begin{array}{l}\text { scale } 1 \text { - } 5 \text { with } 1 \text { - very dissatisfied, and5 = } \\
\text { very satisfied }\end{array}$ \\
\hline $\begin{array}{l}\text { satisfaction with what the person is } \\
\text { doing }\end{array}$ & $\begin{array}{l}\text { Answer to the "satisfaction with what the person is doing: question from the YAPS } \\
\text { survey }\end{array}$ & $\begin{array}{l}\text { scale } 1 \text { - } 5 \text { with } 1 \text { - very dissatisfied, and } 5= \\
\text { very satisfied }\end{array}$ \\
\hline satisfaction with partner & Answer to the "satisfaction with partner: question from the YAPS survey & $\begin{array}{l}\text { scale } 1 \text { - } 5 \text { with } 1 \text { - very dissatisfied, and5 = } \\
\text { very satisfied }\end{array}$ \\
\hline labor market transition & $\begin{array}{l}\text { Dummy variable taking on the value } 1 \text { if the person has achieved her highest } \\
\text { education level after 1999, and is a part of the labor force (not a student, } \\
\text { unemployed, or house worker) in 2009, and } 0 \text { otherwise }\end{array}$ & $\begin{array}{l}0 \text { - other } \\
1 \text { - completed labor market transition }\end{array}$ \\
\hline occupation category & $\begin{array}{l}\text { Classification constructed from two questions: } \\
1 \text { - What is your main occupation? What are your main tasks at work? } \\
2 \text { - What is your current main activity? }\end{array}$ & $\begin{array}{l}\text { Occupation categories used in the paper are } \\
\text { divided into following groups: } \\
\text { 1) Student } \\
\text { 2) Goods production } \\
\text { 3) Service production } \\
\text { 4) Assistnat non-manual } \\
\text { 5) Intermediate non-manual } \\
\text { 6) Professional/higher manual/self- } \\
\text { employed } \\
\text { 7)Executive/entrepreneur/farmer }\end{array}$ \\
\hline
\end{tabular}


Table B3 continued

\begin{tabular}{|c|c|c|}
\hline \multicolumn{3}{|c|}{ Table B3 continued } \\
\hline educ_level & Education from the Swedish register data & $\begin{array}{l}\text { compulsory } 9 \text { years } \\
\text { secondary }<3 \text { years } \\
\text { secondary } 3 \text { years } \\
\text { post-secondary }<3 \text { years } \\
\text { post-secondary }>=3 \text { years/postgraduate }\end{array}$ \\
\hline educ_years & $\begin{array}{l}\text { Years of education constructed based on the education level obtained from } \\
\text { register data }\end{array}$ & $\begin{array}{l}\text { Education years assigned as follows: } \\
\text { compulsory education - } 9 \text { years } \\
\text { secondary less than } 3 \text { years - } 10.5 \text { years } \\
\text { secondary } 3 \text { years - } 12 \text { years } \\
\text { post-secondary less than } 3 \text { years - } 13.5 \text { years } \\
\text { post-secondary more than } 3 \text { years/postgraduate } \\
\text { - } 16.5 \text { years }\end{array}$ \\
\hline marital status & Marital status from Swedish register & $\begin{array}{l}\text { 1. unmarried; 2. married; 3. widowed; } 4 . \\
\text { divorced }\end{array}$ \\
\hline cohort & Register data for year person was born & \\
\hline gender & Register data for gender of person surveyed & \\
\hline county & County of residence from Swedish register & \\
\hline municipality & Municipality of residence from Swedish register & \\
\hline $\begin{array}{l}\text { unmarried FD } \\
\text { married FD } \\
\text { divorced/widowed FD }\end{array}$ & $\begin{array}{l}\text { Change in the corresponding marital status constructed according to the } \\
\text { Swedish register "marital status" variable }\end{array}$ & $\begin{array}{l}\text {-1: person who has exited the corresponding } \\
\text { marital status } \\
0 \text { : person who has had no changes in his/her } \\
\text { marital status } \\
\text { 1: person who has entered the corresponding } \\
\text { marital status }\end{array}$ \\
\hline
\end{tabular}




\begin{tabular}{|c|c|c|}
\hline \multicolumn{3}{|c|}{ Table B4. Description of original survey questions used in the analysis } \\
\hline Variable & Question asked & Response categories \\
\hline life satisfaction & Are you satisfied or dissatisfied with life in general right now? & scale 1 - 5 with 1 - very dissatisfied, and5 = very satisfied \\
\hline Economic satisfaction & Are you satisfied or dissatisfied with your economic situation? & scale 1 - 5 with 1 - very dissatisfied, and5 = very satisfied \\
\hline satisfaction with housing & Are you satisfied or dissatisfied with your housing situation? & scale 1 - 5 with 1 - very dissatisfied, and $5=$ very satisfied \\
\hline satisfaction with what the person is doing & Are you satisfied or dissatisfied with what you are currently doing? & scale 1 - 5 with 1 - very dissatisfied, and5 = very satisfied \\
\hline satisfaction with partner & Are you satisfied or dissatisfied with your relationship with your partner? & scale 1 - 5 with 1 - very dissatisfied, and5 = very satisfied \\
\hline long_distance_move & When did you last make a long distance move? (year and month) & Year and month recorded separately \\
\hline reason_move & What was the most important reason for you to move? & $\begin{array}{l}\text { My work/studies } \\
\text { My partners work/studies } \\
\text { I wanted to move to my partner } \\
\text { I wanted to come closer to friends and family } \\
\text { I wanted a change of environment } \\
\text { I wanted to move back to where I grew up } \\
\text { My partner wanted to move } \\
\text { Other, namely..... }\end{array}$ \\
\hline occupation & What is your main occupation? What are your main tasks at work? & $\begin{array}{l}\text { Open ended response from survey regrouped as: } \\
\text { 1.unskilled in good production } \\
\text { 2.unskilled in service production } \\
\text { 3.skilled in goods production } \\
\text { 4.skilled in service production } \\
\text { 5.assistant non-manual, lower level i } \\
\text { 6.assistant non-manual, lower level ii } \\
\text { 7.intermediate non-manual } \\
\text { 8.professional/higher non-manual/self-employed } \\
\text { 9.entrepreneurs/farmers/executives }\end{array}$ \\
\hline main activity & What is your current main activity? & $\begin{array}{l}\text { Open ended response from survey regrouped as: } \\
\text { 1. permanent employment } \\
\text { 2. casual/limited employment } \\
\text { 3. self employed } \\
\text { 4. studies } \\
\text { 5. "kunskapslyftetet" } \\
\text { 6. employment measures } \\
\text { 7. unemployed }>=6 \text { months } \\
\text { 8. unemployed }<6 \text { months } \\
\text { 9. parental leave } \\
\text { 10. housekeeping } \\
\text { 11. military } \\
\text { 13. retired } \\
\text { 14. on long term sick leave } \\
\text { 15. doctoral student } \\
\text { 16. on leave from work } \\
\text { 17. other }\end{array}$ \\
\hline
\end{tabular}




\section{Appendix C. Robustness checks}

\begin{tabular}{|c|c|c|c|c|c|c|}
\hline & \multicolumn{6}{|c|}{ Life satisfaction } \\
\hline & (1) & (2) & (3) & (4) & (5) & (6) \\
\hline & \multicolumn{2}{|c|}{ OLS } & \multicolumn{2}{|c|}{ OLS } & \multicolumn{2}{|c|}{ MI ICE } \\
\hline \multirow[t]{2}{*}{ all migrants } & 0.214 & 0.183 & & & & \\
\hline & $(3.29)^{\star \star}$ & $(2.72)^{\star \star}$ & & & & \\
\hline \multirow[t]{2}{*}{ work migrant } & & & 0.27 & 0.231 & 0.270 & 0.232 \\
\hline & & & $(2.93)^{\star \star}$ & $(2.45)^{\star}$ & $(2.77)^{\star \star}$ & $(2.35)^{\star}$ \\
\hline \multirow[t]{2}{*}{ non-work migrant } & & & 0.175 & 0.149 & 0.172 & 0.147 \\
\hline & & & $(2.08)^{\star}$ & $(1.76)+$ & $(2)^{\star}$ & $(1.69)+$ \\
\hline \multirow[t]{2}{*}{ married FD } & & 0.015 & & 0.015 & & 0.015 \\
\hline & & $(0.27)$ & & $(0.28)$ & & $(0.28)$ \\
\hline \multirow{2}{*}{ divorced/widowed FD } & & -0.055 & & -0.056 & & -0.056 \\
\hline & & $(0.37)$ & & $(0.38)$ & & $(0.43)$ \\
\hline \multirow[t]{2}{*}{ Im_transition } & & 0.116 & & 0.114 & & 0.114 \\
\hline & & $(2.05)^{\star}$ & & $(2.01)^{\star}$ & & $(2.02)^{\star}$ \\
\hline \multirow[t]{2}{*}{ Constant } & 0.02 & -0.014 & 0.021 & -0.013 & 0.020 & -0.013 \\
\hline & $(0.35)$ & $(0.21)$ & $(0.36)$ & $(0.2)$ & $(0.35)$ & $(0.2)$ \\
\hline Observations & 1541 & 1526 & 1538 & 1524 & 1541 & 1526 \\
\hline R-squared & 0.03 & 0.03 & 0.03 & 0.03 & & \\
\hline
\end{tabular}


Table C2. OLS and MI ICE regressions: Different life domains as dependent variables, regressed on county migrant dummy (pooled and by reason)

\begin{tabular}{|c|c|c|c|c|c|c|c|c|c|c|c|c|c|c|c|}
\hline & (1) & $(2)$ & (3) & (4) & (5) & (6) & (7) & $(8)$ & (9) & $(10)$ & (11) & $(12)$ & (13) & (14) & (15) \\
\hline & \multicolumn{9}{|c|}{ Economic domain } & \multicolumn{3}{|c|}{ Housing domain } & \multicolumn{3}{|c|}{ Professional domain } \\
\hline & \multicolumn{3}{|c|}{ Work income } & \multicolumn{3}{|c|}{ Disposable income } & \multicolumn{3}{|c|}{ Economic satisfaction } & \multicolumn{3}{|c|}{$\begin{array}{c}\text { Satisfaction with } \\
\text { housing }\end{array}$} & \multicolumn{3}{|c|}{$\begin{array}{l}\text { Satisfaction with what } \\
\text { currently doing }\end{array}$} \\
\hline & OLS & OLS & MI ICE & OLS & OLS & MI ICE & OLS & OLS & MI ICE & OLS & OLS & MI ICE & OLS & OLS & MI ICE \\
\hline \multirow[t]{2}{*}{ all migrants } & 23.134 & & & 9.73 & & & -0.032 & & & 0.18 & & & -0.128 & & \\
\hline & $(2.54)^{\star}$ & & & $(1.55)$ & & & $(0.38)$ & & & $(1.93)+$ & & & $(1.46)$ & & \\
\hline \multirow[t]{2}{*}{ work migrant } & & 41.332 & 41.824 & & 21.323 & 21.684 & & 0.005 & 0.007 & & 0.08 & 0.084 & & -0.152 & -0.148 \\
\hline & & $(2.91)^{\star \star}$ & $(3.15)^{\star \star}$ & & $(2.16)^{*}$ & $(2.5)^{\star}$ & & $(0.05)$ & $(0.06)$ & & $(0.58)$ & $(0.66)$ & & $(1.25)$ & $(1.17)$ \\
\hline \multirow[t]{2}{*}{ non-work migrant } & & 10.579 & 9.257 & & 1.625 & 0.853 & & -0.054 & -0.060 & & 0.253 & 0.252 & & -0.119 & -0.112 \\
\hline & & $(0.96)$ & $(0.79)$ & & $(0.21)$ & $(0.11)$ & & $(0.52)$ & $(0.59)$ & & $(2.28)^{\star}$ & $(2.25)^{*}$ & & $(1.05)$ & $(1.01)$ \\
\hline \multirow[t]{2}{*}{ married FD } & 5.049 & 5.131 & 5.307 & 13.59 & 13.592 & 13.755 & 0.052 & 0.053 & 0.053 & -0.023 & -0.027 & -0.024 & -0.034 & -0.038 & -0.034 \\
\hline & $(0.64)$ & $(0.65)$ & $(0.72)$ & $(2.70)^{\star \star}$ & $(2.70)^{\star \star}$ & $(2.84)^{\star \star}$ & $(0.8)$ & $(0.81)$ & $(0.81)$ & $(0.33)$ & $(0.39)$ & $(0.34)$ & $(0.47)$ & $(0.53)$ & $(0.48)$ \\
\hline \multirow[t]{2}{*}{ divorced/widowed FD } & 19.901 & 19.418 & 19.484 & 30.868 & 30.531 & 30.602 & -0.148 & -0.148 & -0.149 & -0.218 & -0.217 & -0.215 & 0.088 & 0.087 & 0.089 \\
\hline & $(1.35)$ & $(1.31)$ & (1.11) & $(2.81)^{\star \star}$ & $(2.77)^{\star \star}$ & $(2.68)^{\star \star}$ & $(0.85)$ & $(0.85)$ & $(0.96)$ & (1.32) & $(1.32)$ & (1.28) & $(0.6)$ & $(0.59)$ & (0.53) \\
\hline \multirow[t]{2}{*}{ Im_transition } & 66.656 & 65.991 & 65.794 & 14.383 & 13.985 & 13.832 & 0.532 & 0.531 & 0.531 & -0.028 & -0.022 & -0.024 & 0.127 & 0.13 & 0.128 \\
\hline & $(8.52)^{\star \star}$ & $(8.41)^{\star \star}$ & $(8.69)^{\star \star}$ & $(3.02)^{\star \star}$ & $(2.95)^{\star \star}$ & $(2.8)^{\star \star}$ & $(7.78)^{\star \star}$ & $(7.72)^{\star \star}$ & $(8)^{\star \star}$ & $(0.38)$ & $(0.29)$ & $(0.33)$ & $(1.77)+$ & $(1.80)+$ & $(1.76)+$ \\
\hline \multirow[t]{2}{*}{ Constant } & 100.106 & 100.281 & 100.286 & 104.361 & 104.519 & 104.476 & 0.196 & 0.196 & 0.196 & 0.439 & 0.44 & 0.438 & 0.111 & 0.115 & 0.111 \\
\hline & $(9.23)^{\star \star}$ & $(9.25)^{\star \star}$ & $(11.47)^{\star \star}$ & $(13.51)^{\star \star}$ & $(13.53)^{\star \star}$ & $(18.29)^{\star \star}$ & $(2.57)^{\star}$ & $(2.56)^{\star}$ & $(2.57)^{\star \star}$ & $(4.91)^{\star \star}$ & $(4.92)^{\star \star}$ & $(5.18)^{\star \star}$ & $(1.38)$ & $(1.42)$ & (1.33) \\
\hline Observations & 1556 & 1554 & 1556 & 1556 & 1554 & 1556 & 1540 & 1538 & 1540 & 1530 & 1528 & 1530 & 1508 & 1506 & 1508 \\
\hline R-squared & 0.11 & 0.12 & & 0.07 & 0.07 & & 0.08 & 0.08 & & 0.03 & 0.03 & & 0.02 & 0.02 & \\
\hline \multicolumn{16}{|c|}{ Robust t statistics in parentheses } \\
\hline \multicolumn{16}{|c|}{ + significant at $10 \% ;{ }^{*}$ significant at $5 \% ;{ }^{* *}$ significant at $1 \%$} \\
\hline \multicolumn{16}{|c|}{ All regressions include county controls corresponding to $D_{c o}$ and $\left(D_{c 1}-D_{c o}\right)$ from model $(2 b)$. } \\
\hline
\end{tabular}




\begin{tabular}{|c|c|c|c|}
\hline \multicolumn{4}{|c|}{$\begin{array}{l}\text { Table C3. OLS and MI ICE regressions: Life satisfaction as dependent variable, } \\
\text { regressed on migrant dummy (pooled and by reason) with non-migrants as } \\
\text { reference group, controlling for years of education changes }\end{array}$} \\
\hline & \multicolumn{3}{|c|}{ Life satisfaction } \\
\hline & (1) & $(2)$ & (3) \\
\hline & OLS & OLS & MI ICE \\
\hline \multirow[t]{2}{*}{ all migrants } & 0.179 & & \\
\hline & $(3.21)^{\star \star}$ & & \\
\hline \multirow[t]{2}{*}{ work migrant } & & 0.225 & 0.233 \\
\hline & & $(2.79)^{\star \star}$ & $(2.85)^{\star \star}$ \\
\hline \multirow[t]{2}{*}{ non-work migrant } & & 0.138 & 0.151 \\
\hline & & $(2.07)^{\star}$ & $(2.35)^{\star}$ \\
\hline \multirow{2}{*}{ married FD } & 0.01 & -0.001 & 0.011 \\
\hline & $(0.19)$ & $(0.01)$ & $(0.19)$ \\
\hline \multirow[t]{2}{*}{ divorced/widowed FD } & -0.047 & -0.072 & -0.049 \\
\hline & $(0.31)$ & $(0.46)$ & $(0.38)$ \\
\hline \multirow[t]{2}{*}{ Im_transition } & 0.084 & 0.106 & 0.08 \\
\hline & $(0.79)$ & $(0.96)$ & $(0.79)$ \\
\hline \multirow[t]{2}{*}{ educ_years FD } & 0.008 & 0.006 & 0.008 \\
\hline & $(0.27)$ & $(0.19)$ & $(0.27)$ \\
\hline \multirow[t]{2}{*}{ Constant } & -0.069 & -0.065 & -0.069 \\
\hline & $(0.98)$ & $(0.88)$ & $(1)$ \\
\hline Observations & 1523 & 1451 & 1523 \\
\hline R-squared & 0.03 & 0.04 & \\
\hline \multicolumn{4}{|c|}{ Robust t statistics in parentheses } \\
\hline \multicolumn{4}{|c|}{ + significant at $10 \% ;{ }^{*}$ significant at $5 \% ;{ }^{* \star}$ significant at $1 \%$} \\
\hline
\end{tabular}


